\title{
Structural development of the Lower Paleozoic belt of South China: Genesis of an intracontinental orogen
}

\author{
Jacques Charvet ${ }^{\underline{a}}$, Liangshu Shu ${ }^{\underline{b}}$, Michel Faure ${ }^{\underline{a}}$, Flavien Choulet ${ }^{\underline{a}}$, Bo Wang ${ }^{\underline{b}}$, Huafu \\ $\mathbf{L u}^{\mathbf{b}}$ and Nicole Le Breton ${ }^{\underline{\mathbf{a}}}$
}

${ }^{\text {a } I n s t i t u t ~ d e s ~ S c i e n c e s ~ d e ~ l a ~ T e r r e ~ d ' O r l e ́ a n s ~(I S T O), ~ U M R ~ 6113, ~ 1 A ~ r u e ~ d e ~ l a ~ F e ́ r o l l e r i e, ~}$ 45100 Orléans, France

${ }^{\mathrm{b}}$ State Key Laboratory for Mineral Deposits Research, Department of Earth Sciences, Nanjing University, Nanjing 210093, China

\begin{abstract}
An extensive structural study of Wuyishan and surrounding areas (South China) brings data on the structures formed prior to the Devonian unconformity, building the Lower Paleozoic belt. An Ordovician tectonic event was responsible for: (i) south-directed structures in the Wuyishan proper and its southern border, related to both thin and thick-skinned tectonics, accompanied by metamorphism and crustal thickening; (ii) north-directed structures to the west of Ganjiang Fault and north of Jiangshan-Shaoxing Fault, where only thin-skinned tectonics is visible. The southward deformation accommodating the shortening includes emplacement of thrust sheets, involving deep crustal material and some mantle peridotite, and likely repetition of continental material, both responsible for crustal thickening. The orogeny was due to the underthrusting of the southern part of the South China Block beneath the northern part of this block, closing the pre-existing Nanhua rift, created at around 850$800 \mathrm{Ma}$, and involving the rift sedimentary fill in the southward thrusting. The synmetamorphic tectonic piling was followed by anatexis and granite emplacement at around 440-390 Ma. Our new U-Th-Pb EPMA monazite dating gives ages of $433 \pm 9 \mathrm{Ma}$ and $437 \pm 5 \mathrm{Ma}$ (Early Silurian) for the main anatectic event, and a younger age of $412 \pm 5 \mathrm{Ma}$ (Late Silurian-Early Devonian) for a late re-heating process. The Lower Paleozoic belt is an intracontinental orogen, without oceanic suture record. It shows some similarities with the Cenozoic European Pyrénées Chain, with a strong asymmetry.
\end{abstract}

Keywords: South China; Early Paleozoic; Tectonics; Geodynamics

\section{Introduction}

The South China Block is composed of the Yangtze Block to the north and the Cathaysian Block to the south (YB and CB, Fig. 1) which amalgamated during the Neo-proterozoic around $900 \mathrm{Ma}$ ([Guo et al., 1985], [Guo et al., 1989], [Chen et al., 1991], [Xu et al., 1992], [Shu et al., 1994], [Shu and Charvet, 1996], [Charvet et al., 1996], [Li, 1998], [Ye et al., 2007], [Li et al., 2008] and [Chen et al., 2009]); the northward subduction of the ocean between the Yangtze and Cathaysia Blocks induced a volcanic arc, on the southern margin of Yangtze Block, which was active at around $970 \mathrm{Ma}$ (Gao et al., 2009). The oceanic closure may have been diachronous (Li et al., 2007): $\geqslant 1000 \mathrm{Ma}$ to the west and ca. $900 \mathrm{Ma}, 880 \mathrm{Ma}$ (Li et al., 2009a), at the eastern part of the orogen; some authors argue for a closing age not older than $860 \mathrm{Ma}$ (Wang et al., 2007). 
The Cathaysia comprises a NE-SW trending orogen, stretching for ca. $2000 \mathrm{~km}$ (e.g., Ren et al., 1997) and possibly extending to the Korean peninsula (e.g., [Cluzel et al., 1991] and [Kim et al., 2006]) and to the Indochina Block ([Ren, 1991], [Carter et al., 2001], [Nagy et al., 2001], [Roger et al., 2007] and [Lepvrier et al., 2008]).

This orogen, called the South China Caledonian Fold Belt (e.g. Huang, 1978), Cathaysian or Huanan Caledonides (e.g. [Ren, 1991], [Chang, 1996] and [Charvet, 1999]), WuyishanYunkaidashan belt (e.g. Zhang et al., 1984), Wuyi-Yunkai tectonic zone (Zhang et al., 1991), Early Paleozoic Orogen of the South China Block (Faure et al., 2009) or Wuyi-Yunkai orogen (Li et al., 2009b) in the literature, has been recognized as Early Paleozoic in age due to the angular unconformity between pre-Devonian deformed rocks and Devonian strata ([Grabau, 1924], [Ren, 1964], [Ren, 1991], [Huang et al., 1980] and [Zhao et al., 1996]). It includes Neo-proterozoic-Lower Paleozoic non-metamorphic or low grade metamorphic sediments, Paleoproterozoic to Lower Neo-proterozoic ([Li, 1997] and [Li et al., 2002]) high grade metamorphic rocks, migmatites and granitoids. The high grade metamorphic rocks occur mainly in the northeastern segment, including northern Fujian and southern Zhejiang provinces, and in Nanling zone (e.g., [FBGMR, 1985], [Shui et al., 1988], [Li, 1988], [Li, 1989], [ZBGMR, 1989], [Hu et al., 1991], [Gan et al., 1993], [Gan et al., 1995], [Li et al., 1993], [Zhao and Cawood, 1999] and [Yu et al., 2006]). Recent studies of metamorphic and magmatic rocks point out the importance of the Early Paleozoic metamorphism and granitic intrusions ([Li et al., 2003a], [Li et al., 2003b], [Li et al., 2009a], [Sun, 2006], [Wan et al., 2007], [Chen et al., 2008] and [Zeng et al., 2008]) and existence of inherited zircons revealing the presence of an old basement ([Li et al., 1989], [Gan et al., 1996], [Yu et al., 2006], [Xu et al., 2005] and [Xu et al., 2007]). Therefore, the pre-Devonian deformation and metamorphism affected Neo-proterozoic-Lower Paleozoic protoliths, and remobilized the older basement.

This belt has been interpreted in different ways: (i) intracontinental orogen ([Ren et al., 1986], [Ren et al., 1987], [Ren and Chen, 1989], [Chang, 1996], [Charvet, 1999], [Wang et al., 2007], [Shu et al., 2008b] and [Faure et al., 2009]); (ii) collision belt ([Wang et al., 1988], [Guo et al., 1989], [Jahn et al., 1990], [Hsü et al., 1990], [Li, 1993] and [Ma, 2006]). A northwestward vergence has been advocated in the metamorphic rocks ([Ren, 1964], [Ren, 1991] and [Shui et al., 1988]). The deformation is also reported to have affected the cover strata of the Yangtze craton in the northwestern part of the South China Block, with a decreasing deformation intensity towards the northwest (Ren, 1964), as a fold and thrust belt (Li, 1998). Some southverging structures have been described in the Wuyishan, especially in the metamorphic rocks ([Charvet, 1999] and [Shu et al., 1999]). However, so far, precise structural data are rare and the vergence of structures is poorly documented, precluding the construction of a geodynamic model based on robust data.

The aim of this paper is to provide some evidence of deformation kinematics for the Wuyishan area (Zhejiang, Fujian and a part of Jiangxi provinces) and, using age constraints brought by recently published and new data, to propose a model of the tectonic evolution of the Lower Paleozoic orogen.

\section{Geological setting}

The study area (Fig. 1) is located in the northeastern part of the belt; it includes southwest Zhejiang, northern Fujian, and a small part of Jiangxi. It is composed of the following lithotectonic units: Mesozoic-Cenozoic volcanic and sedimentary strata; a sequence of Upper Paleozoic to Lower-Middle Triassic strata, which were affected by the Triassic Indosinian 
orogeny; Upper Neo-proterozoic (Sinian) to Ordovician weakly metamorphosed sediments; high grade metamorphic rocks derived from Proterozoic basement or Neo-proterozoic-Lower Paleozoic protolith. This area also shows intrusive plutons: Early Paleozoic, Triassic, Jurassic and Cretaceous granitoids.

The whole domain is cut by NE-trending faults, considered as Indosinian-Yanshanian (Triassic-Cretaceous); the ENE trending Jiangshan-Shaoxing Fault is a major one ([Shui et al., 1986], [Li and Mooney, 1998] and [Xiong and Liu, 2000]), bounding to the north the metamorphic domain; active as a fault since the Late Paleozoic (Xu et al., 1994), it may overprint a Neo-proterozoic suture zone (e.g. [Zhou and Zhu, 1993] and [Shu et al., 2008a]).

The high grade regional metamorphic rocks were considered as representing the Proterozoic basement; usually divided into the Badu Group in Zhejiang (west of Longquan, Fig. 1), and the Mayuan Group in northern Fujian. They consist mainly of felsic gneiss, often fine-grained, migmatite, amphibolite, quartzite, and marble. To the west of Jianning, in western Fujian, they correspond to the Tianjingping Formation, comprising graphite-garnet-kyanitesillimanite-bearing schist, fine-grained gneiss, and amphibolite.

The Badu Group yielded zircon U-Pb ages of ca. $2 \mathrm{Ga}$ (Hu et al., 1991); syn to post-tectonic granites, with conventional zircon $\mathrm{U}-\mathrm{Pb}$ ages of $1.8-1.9 \mathrm{Ga}$, constrain the time of metamorphism and deformation at around $1800 \mathrm{Ma}$ ([Hu et al., 1991], [Hu et al., 1992] and [Gan et al., 1995]), in the interval 1850-1781 Ma ([Xiang et al., 2008] and [Li et al., 2009b]); recent LA-ICPMS zircon U-Pb ages indicate that magmatism and metamorphism took place between 1888 and $1855 \mathrm{Ma}$ (Yu et al., 2009). The Mayuan Group yielded conventional zircon $\mathrm{U}-\mathrm{Pb}$ ages of around 1.4 and $1.1 \mathrm{Ga}$ and was considered to be metamorphosed at around $850 \mathrm{Ma}$ ([Xu and Shui, 1988], [Li, 1989] and [Gan et al., 1993]). However, recent datings reveal that some of these rocks have a protolith age not older than $807 \mathrm{Ma}$ and were metamorphosed at around 460 Ma during the Early Paleozoic orogeny (Wan et al., 2007). The Tianjingping Formation contains amphibolite with a protolith age of $1766 \pm 19 \mathrm{Ma}(\mathrm{Li}, 1997)$ and detrital zircons of 3.6-2.5 Ga ([Xu et al., 2005] and [Yu et al., 2006]), but was strongly remobilized by crustal melting at around 446-425 Ma (Wan et al., 2007). Thus, several units of micaschist and gneiss, previously assigned to Paleo-Mesoproterozoic, derive from a protolith younger than $800 \mathrm{Ma}$ and were metamorphosed during the Early Paleozoic orogeny. They usually include meta-volcanic or meta-volcanic-sedimentary rocks; the significance of these protoliths has been debated but is now generally interpreted as the result of a rifting that occurred between 830 and $700 \mathrm{Ma}$ ([Gilder et al., 1991], [Wang and Li, 2003], [Li et al., 2003b] and [Li et al., 2005]). A clue of the Neo-proterozoic belt was recently found in southern Cathaysian Block, where a meta-rhyolite and detrital zircons in gneiss and orthogneiss were dated at ca. $1000 \mathrm{Ma}$ ([Shu et al., 2008c], [Wan et al., 2007] and [Wang et al., 2008]), suggesting a Grenvillian event.

The Nanhua rift took place after the collision of the Yangtze and Cathaysia Blocks (Jinning or Sibao orogeny), the latter creating the Jiangnan belt ([Chen et al., 1991], [Xu et al., 1992], [Shu et al., 1994], [Shu et al., 2006], [Charvet et al., 1996], [Charvet, 1999] and [Shu and Charvet, 1996]). In addition, slices of mafic and ultramafic rocks: gabbro, basalt, peridotite, serpentinite, are also present in the northeastern part of the studied area, especially beween Jian'ou and Zhuji (Fig. 1). Those rocks yielded ages around 850-830 Ma ([Kong et al., 1995] and [Shu et al., 2006]), and have been regarded as possible relics of the Jiangnan ophiolites (Charvet et al., 1999) or of another suture zone, scar of a South China Ocean closed at 900$850 \mathrm{Ma}$ (Wang and Shu, 2007). But their age, definitely younger than the Jiangnan ophiolites, 
argues against the former hypothesis; and their dominant alkaline-type geochemistry contradicts the second one. The likely interpretation is that they represent the result of the Nanhua rifting, post-dating the Jiangnan collision. This rift aborted, did not reach the oceanic spreading stage, and lasted from 850 to $740 \mathrm{Ma}$ ([Wang and Li, 2003] and [Li et al., 2003b]). Some authors link this rifting with the break-up of Rodinia, maybe due to a mantle plume ([Li et al., 2003a], [Li et al., 2005] and [Li et al., 2008]), others with post-collisional lithospheric extension (Zheng et al., 2008).

The Sinian-Ordovician sedimentary sequence is different to the south and to the north of the Jiangshan-Shaoxing Fault. To the north, in Jiangshan area, it consists of a succession of Sinian conglomerate, tuffaceous sandstone, and black limestone; Cambrian dolomite with coal layers and nodular limestone; Ordovician sandstone and turbidite. The Ordovician flysch is younging towards the NW and may reach the Silurian ([HBGMR, 1988] and [Rong et al., 2003]). These unmetamorphosed platform strata were deformed as SW-NE trending folds, upright to slightly overturned toward the NW. To the south, in western Fujian and southern Jiangxi, the Sinian-Ordovician formations are represented by a thick pile (7-8 km) of phyllite, slate, meta-shale and meta-sandstone. These formations were metamorphosed in the subgreenschist to lower-greenschist facies. They are overlain unconformably by conglomerate of the Middle Devonian Tiaomajian Formation. The Silurian is lacking in the Wuyishan.

The Upper Paleozoic-Middle Triassic sequence is made of a succession of shallow-marine and shore deposits: Upper Devonian conglomerate and sandstone, Carboniferous-Lower Permian carbonate, Upper Permian shale-sandstone with coal beds, Lower-Middle Triassic limestone and siltstone. The thickness, about $2.5 \mathrm{~km}$ to the north, reaches $3 \mathrm{~km}$ in southeast Fujian ([Shu et al., 2006] and [Shu et al., 2008a]). These formations were affected by the Triassic (Indosinian) event and are unconformably overlain by the Upper Triassic conglomerate.

The Mesozoic-Cenozoic formations are mainly represented by terrigenous deposits of intramontane basins (Shu et al., 2009) and volcanic or volcaniclastic rocks linked to the Pacific subduction. Abundant Jurassic-Cretaceous (Yanshanian) plutons intrude the previous structures.

\section{Early Paleozoic deformation}

The structures created by the Early Paleozoic orogeny and their vergence are rather easily deciphered in the weakly metamorphosed Sinian-Ordovician strata, which we call the sedimentary units. The situation in the high grade metamorphic units is more complicate, as the Early Paleozoic deformation may overprint earlier structures developed in the Proterozoic basement.

\subsection{Sedimentary units}

Depending on the locality, the sedimentary units show a southern vergence or a northern one.

In the southern Wuyishan, between Dabodi and Sanming (Fig. 1), the southern vergence predominates. A first example is observed in the Sanming-Xingkou area (Fig. 2).

The Sinian-Cambrian sandstone and shale are tightly folded and affected by a cleavage which is vertical or steeply dipping northwestward (Fig. 2a). These structures were formed prior to 
Devonian unconformity. They are cut by flat-lying brittle thrusts likely due to the Triassic reworking, as similar thrust planes affect the Devonian (Fig. 2b) and the Upper Paleozoic sequence as a whole (Fig. 2c). On the cleavage plane, a stretching lineation is poorly developed, trending N180-200. Pre-Devonian granites are deformed with a foliation dipping north or vertical (Fig. 2a and c).

A second example is provided by the Qingliu-Quanshang area (Fig. 3). The Anle section (Fig. 3b) shows tightly folded Sinian slates, in tectonic contact (N40 dextral ductile shear zone) with the Silurian Ninghua granite. Triassic thrusts affect the non-shistose CarboniferousPermian strata. The cleavage in the Sinian-Cambrian slates dip towards the NW and bears a stretching lineation, oriented N120-N195. The Qingliu section (Fig. 3c) shows the Cambrian muddy slate and meta-sandstone affected by tight folding, with some limbs overturned toward the SE, the schistosity dipping to the NW. The stretching lineation is trending N100-N160. Similar features are exposed in Quanshang-Gaian area (Fig. 3a) with a scattered lineation N90-N170.

In thin section, cut along the $X Z$ plane, most of the kinematic criteria indicate a top-to-thesouth shearing (Fig. 4a-e). A few of them, assigned to a late collapse phase, are north-directed (Fig. 4f). In weakly metamorphosed schists exposed to the south of Shaowu and in the Dabodi-Ruijin area, the sense of shearing is also in average toward the south or southwest (Fig. 1).

To the west of Ganjiang Fault (Fig. 1), NW-SE trending folds develop in the Cambrian phyllite and meta-sandstone (JBGMR, 1984). Rather tight, they are upright to slightly overturned toward the NE (Fig. 5). A S1 crenulation cleavage affects the Cambrian. Locally, near the N80 trending strike-slip fault bounding a contact with Devonian conglomerate, a S2 cleavage develops and affects both the Devonian and Cambrian. To the south of this section, around Xiazhuang in Jinggangshan area, the Upper Cambrian slate, meta-sandstone and flysch-like sequence show at the outcrop scale several indicators of top-to-the-north shearing: S-C composite foliation fabric and sigmoids. Near Huangao in the same area, the Middle Ordovician strata are involved in an asymmetric fold with a steep northern limb and a gentle southern one; the cleavage is sub-parallel to the southern limb strata. In both areas, the trend of stretching lineation varies from N-S to N140. In thin section, kinematic criteria indicate clearly a top-to-the-north sense of shearing (Fig. $4 \mathrm{~g}$ and $\mathrm{h}$ ). In the triangular area between the Ganjiang and Jiangshan-Shaoxing Faults (Fig. 1), the pre-Devonian deformation is verging to the north, at macroscopic and microscopic scales.

To the north of the Jiangshan-Shaoxing Fault, in Yushan-Jiangshan area (Fig. 1), the vergence is also toward NW; but the deformation is limited to rather open buckle folds involving pre-Triassic strata, without penetrative cleavage. An axial plane fan-shaped fracture cleavage develops locally and some folds are asymmetric, slightly overturned (Fig. 6a). These structures indicate a NW-verging thin-skinned tectonic style.

In summary, the Ganjiang and Jiangshan-Shaoxing Faults limit two domains. On the southeastern side of Jiangshan-Shaoxing Fault, east of Ganjiang Fault, the Sinian-Cambrian meta-sediments show a ductile deformation with a southward vergence. On the northwestern side of Jiangshan-Shaoxing Fault and the western side of Ganjiang Fault, the vergence is toward the north, expressed in a more ductile way in the latter area. 


\subsection{High grade metamorphic units}

The assemblages of gneiss, micaschist, quartzite, marble, amphibolite, of upper greenschist to amphibolite facies cropping out in the area between Yingtan-Pucheng and Jianning-Nanping parallels ([Fig. 1] and [Fig. 7]) show also clear kinematic features. For some of them, the Early Paleozoic age is documented, as recent datings give for protolith ages ranging from 826 to $728 \mathrm{Ma}$ and metamorphic ages around 460-440 Ma ([Li, 1997], [Wan et al., 2007] and [Chen et al., 2008]). It is suggested that no metamorphism nor deformation occurred between $800 \mathrm{Ma}$ and $450 \mathrm{Ma}$ ([Li et al., 2003b] and [Li et al., 2005]). For the areas where a Paleo to Mesoproterozoic basement is possibly existing ([Fig. 1] and [Fig. 7]), the age of preserved microstructures is less easy to assess and needs some discussion.

Another point to consider is the place of deformation in the metamorphic history of rocks. The evolution of metamorphic conditions established for the Mayuan Group records a succession of parageneses (Zhao and Cawood, 1999); a medium temperature-high pressure stage, reaching locally a kyanite-bearing metamorphic assemblage, with granulite inclusions (Yu et al., 2006), was followed by a high temperature stage characterized by sillimanitebearing assemblage, and then by a retrograde chlorite-rich paragenesis. The clockwise $P-T$ path shows a peak of pressure of about $1 \mathrm{Gpa}$, and a maximum temperature of about $600{ }^{\circ} \mathrm{C}$ (Zhao and Cawood, 1999). It implies a burial of ca. $30 \mathrm{~km}$, likely due to crustal thickening (Zhao and Cawood, 1999), responsible for prograde metamorphism with increasing pressure, followed by a high temperature and lower pressure exhumation stage, accompanied by crustal melting, as documented in southern Jiangxi (Faure et al., 2009). Therefore, in the sillimanitebearing rocks, where the kyanite is not or poorly preserved, one should check if the recorded deformation was linked with a secondary anatectic doming during exhumation, rather than the effect of the initial shortening event. Assigned to the former case are the microstructures associated with high temperature paragenesis borne by a foliation turning around an area of migmatite outcrops, where the shear sense is frequently directed downdip on the foliation plane. Fortunately, the growth of sillimanite is quite often cross-cutting the foliation and respecting microstructures (kinematic indicators) formed during the initial stage; and some kinematic criteria, visible in neosome-poor metatexites, are in agreement with the regional strain expressed in purely metamorphic rocks, apparently not linked with the geometry of a dome.

This is the case for instance to the west of Jianning ([Fig. 1] and [Fig. 7]), to the north of the Ninghua pluton, where the sillimanite gneiss yields several kinematic criteria indicating a topto-the-south shearing on a north-dipping foliation (Fig. 6b), similar to the criteria found in neighbouring schists (Fig. 6c); the migmatite may show sheath-like folds (Fig. 6d). Another example is provided by the sillimanite-bearing micaschists of Lukou, to the west of Jianyang (Fig. 8); the high temperature metamorphism is responsible for the occurrence of sillimanite and likely for the static recrystallization of quartz (Fig. 9a and b), but did not erase the top-toN220 kinematics on an eastward dipping foliation observed on the eastern side of the 441 Maold granite. The presence of sillimanite post-dating the main deformation is also clear in the paleosome of the migmatitic gneiss to the north of Cizhu granite, close to the JiangshanShaoxing Fault (Fig. 9c-f). The sillimanite may be associated with late muscovite, also oblique on the main foliation. But in some cases it occurs to be well oriented along the foliation plane.

In the whole area of Fig. 7, almost all lineations, scattered but roughly showing a $\mathrm{N}-\mathrm{S}$ trend, are accompanied by kinematic indicators showing a top-to-the south sense of shear (N130- 
N230). This is also observed in the smaller outcrop areas of pre-Mesozoic rocks to the south of Longyou and near Zhuji (Fig. 1).

Such kinematic criteria, indicating a southward displacement, can be found in different lithological units. In the mafic-ultramafic units, e.g. near Jian'ou and Zhenghe ([Fig. 1], [Fig. 7] and [Fig. 10]), they consist mainly of asymmetric pressure shadows around feldspar porphyroclasts (Fig. 10c and e) or shear bands (Fig. 10d). In quartzite, quartz schist, quartzmica schist, the sense of shear is indicated by quartz fabric (Fig. 11a-d), asymmetric pressure shadows around quartz or pyrite (Fig. 11e and f).

The quartz fabric provides information on the temperature (Fig. 11a-d). The dynamic recrystallization mechanisms involved in the deformation are usually bulging (BLG) and subgrain rotation (SGR), suggesting temperatures between 300 and $500{ }^{\circ} \mathrm{C}$ (Stipp et al., 2002). The activated gliding systems, approximately estimated with the rapid "gypsum test plate method", are predominantly basal $<\mathrm{a}>$ and prism $<\mathrm{a}>$ slips, suggesting also low to medium temperatures of activation. In the paragneiss and orthogneiss, gneissic mylonite, migmatite paleosome, the main indicators are: pressure shadows around feldspar or garnet prophyroclasts, mica fish and sigmoidal prophyroclats (Fig. 12a-h).

The migmatites and sillimanite-bearing gneisses show often evidence of post-deformation static recrystallization of quartz (Fig. 9b). As already mentioned, the sillimanite crystals, growing at the expense of biotite, garnet, or kyanite, are often cross-cutting the gneissic foliation and are not associated with a peculiar shearing; the high temperature metamorphic stage, in this case, did not erase the previous fabric which can still be interpreted.

At contrary to the general case, a few lineations are associated with north-directed deformation (Fig. 7). Regarding their interpretation, they can be divided into three categories. The first category corresponds to a late episode of exhumation. For instance, at Anji, near Longquan, several ductile normal faults, dipping northwestward, are linked with kink bands and folds with horizontal axial planes, suggesting a vertical shortening. In thin section, a topto-NW shearing is associated with a late chlorite-bearing paragenesis (Fig. 13a and b). A similar feature is visible to the NE of Wuyishan (Fig. 7), near the Wuyishan-Taining Fault. The second category includes augen gneissic mylonites, with rotated feldspar porphyroclasts, indicating a northward (N340-N40) shearing. It is found mainly in some outcrops in Longquan area (Fig. 7), near Xikou and Shatian localities (Fig. 13c-g). We assume that these structures are inherited from the Proterozoic evolution and preserved in the Badu Group basement, as the fabric is overprinted by static garnets likely due to the Paleozoic metamorphism (Fig. 13d). To the SW of Shatian (Longquan area) such a gneiss is intruded by a granitic body assigned to Late Proterozoic (Li et al., 1993). The third category is made of a few lineations which interpretation is unclear, due to the lack of evidence supporting their age and their position in the metamorphic history. For instance, near Xiaoqiao (SE of Jian'ou, Fig. 7), a muscovite-garnet gneiss shows post-folial shear bands underlined by muscovite, indicating a top-to-N150 shearing (Fig. 12d), which overprints a northward-directed structure indicated by pressure shadows around garnet. The age of the latter is unclear, but might be the relic of a previous event in a rock assemblage possibly of Paleoproterozoic age (Fig. 7). At Zhangcun ([Fig. 1] and [Fig. 13]), garnet amphibolites overlying an augen gneiss show a lineation trending N70, with a top-to-N70 sense of shear. An age of $480 \mathrm{Ma}$ (K-Ar whole rock, ZBGMR, 1989) argues for a Paleozoic structure, in spite of this eastward trend, unusual for the Paleozoic lineations. 
In summary, in the high grade metamorphic rocks of Wuyishan, the southward deformation is predominantly linked to the structures that can be reasonably assigned to the Early Paleozoic event. Most of these structures were generated during the prograde metamorphic stage, interpreted as due to a crustal thickening (Zhao and Cawood, 1999). This arises the problem of megastructures responsible for this thickening, in particular the existence of nappes.

\section{The problem of Early Paleozoic nappes}

The shortening responsible for crustal thickening must be accommodated by large thrust sheets or nappes. So far, partly due to the outcrop conditions, there is no detailed mapping of such structures. However, the existence of thrust sheets has been proposed ([Wang et al., 1988], [Charvet, 1999], [Zhao and Cawood, 1999], [Shu et al., 2006], [Shu et al., 2008b] and [Li et al., 2009a]) but poorly documented. In Jiangxi Province, thrust nappes are not documented yet (Faure et al., 2009). In the metamorphic domain, if several ductile shear contacts, underlined by mylonites, can be seen, the difficulty is to demonstrate that older rocks are overthrusting younger ones, due to the absence of accurate chronological constraints. In other words, it is often difficult to determine if those contacts are thrust planes or décollements. Anyway, some allochthonous units are certain and some others are most likely, as shown by the following examples.

In Chencai-Huaquan area, to the SE of Zhuji ([Fig. 1] and [Fig. 14]), the Chencai metamorphic complex, comprising mafic-ultramafic rocks (Kong et al., 1995) is thrust over a gneiss unit intruded by the Lipu diorite (Shui et al., 1988), which yielded a zircon SHRIMP $\mathrm{U}-\mathrm{Pb}$ age of $841 \pm 6 \mathrm{Ma}$ (Li et al., 2009b). It includes the Chencai mantle peridotite (blastomylonitic Cpx-poor lherzolite), at the base of the unit, the Huaquan gabbro (Fig. 10f) dated at $858 \pm 11 \mathrm{Ma}$ by zircon SHRIMP U-Pb method (Shu et al., 2006), some meta-basalts dated at $832 \pm 7 \mathrm{Ma}$ (Kong et al., 1995), and a meta-gabbro (sill) yielding a metamorphic zircon SHRIMP U-Pb age of $454 \pm 29 \mathrm{Ma}$ and an ${ }^{40} \mathrm{Ar} /{ }^{39} \mathrm{Ar}$ hornblende cooling age of $425.81 \pm 0.95 \mathrm{Ma}$, and a zircon U-Pb age of $1781 \pm 22 \mathrm{Ma}$ for the protolith (Li et al., 2009b). The zircon SHRIMP U-Pb ages of a garnet gneiss (amphibolite facies metamorphism), of a migmatite, and of a gneissic granite are respectively ca. 447, 433, and $435 \mathrm{Ma}$ (Li et al., 2009). The formation age of a meta-rhyolite is similarly dated at $838 \pm 5 \mathrm{Ma}$ ( $\mathrm{Li}$ et al., 2009b). Therefore, the units present at Chencai are made of probable Paleo- to Mesoproterozoic basement, cut by ca. 840-830 Ma intrusions. But the metamorphic and magmatic ages suggest a remobilization: piling of units and subsequent melting, during the Late Ordovician-Early Silurian. The rare kinematic indicators suggest a top-to-the-south ductile shearing, unlike the apparent vergence suggested by the southeastward dip. In Zhenghe area ([Fig. 1] and [Fig. 7]), allochthonous units of meta-basalts and serpentinite overthrust a unit made of amphibole schist, marble, chlorite schist. The tectonic contacts are clearly exposed along the Hudiejie cross-section (Fig. 14b). Muscovite from marble yielded $\mathrm{an}^{40} \mathrm{Ar} /{ }^{39} \mathrm{Ar}$ age of $391 \pm 3 \mathrm{Ma}$ (Shu et al., 1999), which is problematic regarding the geological meaning as it is younger than the migmatites (see below). The diabase of Zhenghe yielded a SHRIMP U-Pb zircon age of $795 \pm 7 \mathrm{Ma}$, likely relative to rifting (Shu et al., 2008a). The kinematic criteria indicate a displacement towards N130-N200 (Fig. 10e). Therefore, the mafic-ultramafic complex, of Neo-proterozoic age, is rooted to the north or northwest. A third example is given by the meta-pillow basalts and meta-basic tuffs of Jian'ou ([Fig. 1], [Fig. 7] and [Fig. 10]), dated at $857 \pm 0.2 \mathrm{Ma}$ and $853 \pm 4 \mathrm{Ma}$ (SHRIMP U-Pb zircon ages, Shu et al., 2008b) and showing complicated geochemical signatures of island-arc and OIB (Wang and Shu, 2007) or EMORB to continental within-plate basalts (Mamberti, 1996). The stretching lineation is trending N130-N210 and the associated kinematic criteria suggest a top-to-the-south shearing 
(Fig. 10). These units, from Zhenghe to Jian'ou, once regarded as possible Neo-proterozoic ophiolitic relicts (e.g. [Charvet, 1999] and [Wang and Shu, 2007]) can no more be considered as ophiolites, derived from an oceanic basin, as we will see hereafter in the discussion.

Other examples of inferred thrust contacts concern a piling of units with a sole of peridotite at the base of the overlying package. This group may include: (i) the contact between an upper unit of gneiss and migmatite (presumably Proterozoic) and a lower one of micaschist and gneiss to the south of Longyou (Fig. 1), underlined by a level of crushed serpentinite at the locality of Baishishantou; the metamorphic age of an orthogneiss of the upper unit is ca. $460 \mathrm{Ma}$ (Li et al., 2009b) and (ii) the contact between gneiss and micaschist underlined by the Beili serpentinite (Fig. 15a). The ductile thrust tectonics is more likely illustrated by the Xiayan section (Fig. 16a), where a northern gneissic unit, with a sole of Dali peridotite, overthrusts a unit of migmatitic gneiss and micaschist (Fig. 12b), which in turn overthrusts a unit of chlorite schist (Fig. 6f), which in turn tectonically overlies the phyllite unit of Sashikou.

Other ductile tectonic contacts, marked by mylonites, are visible: (i) the base of the quarzite unit in the Yongping-Xikeng section (Fig. 15b); (ii) the base of quartzite-schist unit in the Jianyang section ([Fig. 8] and [Fig. 6]); (iii) the contact of the Longbeixi unit over the Dikou unit (Fig. 16b). But, in those examples, we cannot determine if the upper unit is older than the lower one, if the contact is a thrust or a décollement. Regarding the third example, the presence in the Dikou rocks of a former top-to-the-north fabric argues for the relic of old basement. If so, as the paragneiss of the Dikou unit gave an age of $751 \mathrm{Ma}$ (Wan et al., 2007), the quartzite of the upper unit could represent the Sinian, to which it is commonly assigned (FBGMR, 1985). But, the volcanic age of a meta-rhyolite from the lower part of this sequence, dated by the SHRIMP U-Pb zircon method at $818 \pm 9 \mathrm{Ma}$ (Li et al., 2005), argues for a tectonic piling of older rocks over younger ones. The thrust hypothesis is corroborated by a jump in the metamorphic grade, near Zhengxiu, between the sericite phyllite and the overlying garnet biotite schist. Further study and datings are worth for confirming this hypothesis.

In summary, the existence of Early Paleozoic nappes can be assumed for some tectonic units including mantle peridotite; it is strongly suggested for other ones made of high grade metamorphic rocks. But the distinction between thrust and décollement remains to be verified for some ductile tectonic contacts, with the help of more dating and detailed mapping.

\section{Geochronological data}

The available dating results are still rare in the metamorphic domain. Particularly, the Early Paleozoic age of metamorphism and anatexis in areas where a Proterozoic basement is suspected ([Fig. 1] and [Fig. 6]) needs to be ascertained. In order to document that, we performed new radiometric dating on two samples from the Wuyishan area. We selected a locality to the south of Yongping, in northern Wuyishan, and one near Jianning (sample location on Fig. 6). We chosed to perform in situ U-Th-Pb EPMA dating on monazite which allows to constrain the timing of these events supported by textural and geochemical observations. 


\subsection{Analytical procedure}

As monazite structure prevents incorporation of significant common lead amounts and since monazite does not behave as an open-system after its crystallization, $\mathrm{U}-\mathrm{Th}-\mathrm{Pb}$ dating on monazite can be realized from EPMA results. This chemical method was developed by (Suzuki and Adachi, 1991) and (Montel et al., 1996) and Cocherie et al. (1998) and geochronological results are similar to those obtained by isotopic methods ([Cocherie et al., 1998] and [Cocherie et al., 2005]).

Monazite grains were analyzed with a Cameca SX 50 microprobe co-operated by ISTO and BRGM following the detailed analytical procedure provided by Cocherie et al. (1998), with $20 \mathrm{kV}$ for acceleration voltage, $100 \mathrm{nA}$ for beam current and $150 \mathrm{ppm}$ for $\mathrm{U}$, Th and $\mathrm{Pb}$ absolute errors. Individual and isochron age calculations and data sorting were realized by using EPMA/ex program written by Pommier et al. (2002). Following Cocherie and Albarède's isochron method (2001), data were plotted in U/Pb vs. Th/Pb diagram by using Isoplot (Ludwig, 2003). Results validity is given by several parameters such as comparison of best fit line with theorical isochron or comparison of theorical and calculated Mean Square Weight Deviation (MSWD).

\subsection{Analytical results}

\subsubsection{Sample J C01-WU227}

\subsubsection{Description}

Sample JC01 (WU227) is a gneiss. Under optical microscope, it is mainly composed of sericitized K-feldspars, quartz and well-oriented biotites that define the main foliation, which is overprinted by secondary muscovite grains. Rounded apatite associated with zircon and monazite enclosed within biotites can be observed (Fig. 17). Back Scattered Electron (BSE) images of analyzed monazites also show euhedral crystals with prismatic shape, although grains are relatively small $(20-80 \mu \mathrm{m}$, Fig. 17).

\subsubsection{Results}

Data (47 analyses from 9 monazite grains) are well spread in $\mathrm{Th} / \mathrm{Pb}$ vs. U/Pb diagram (Fig. 17), $\mathrm{U} / \mathrm{Pb}$ and $\mathrm{Th} / \mathrm{Pb}$ ratios respectively varying between 2 and 10 and between 25 and 45 . Intercept ages $(\mathrm{Th}-\mathrm{Pb}$ age $=443+31 /-27 \mathrm{Ma}$ and $\mathrm{U}-\mathrm{Pb}$ age $=409+64 /-73 \mathrm{Ma})$ can be calculated at the point where the best fit line (thick solid line) respectively cross-cuts $X$ and $Y$ axes. These intercept ages are similar within the errors bars and the theorical isochron (dashed line) is similar to the best fit line within its error envelope (thin solid line). As calculated MSWD (0.78) is lower than theoretical one (1.41), validity criteria are statistically satisfied for the age of $433 \pm 9 \mathrm{Ma}$.

\subsubsection{Sample JC02-WU816}

\subsubsection{Description}

This rock is an anatectic granite and does not show any preferred orientation, with clusters of slightly chloritized biotites and muscovites in a quartz-feldspar groundmass. Relics of sillimanite fibres can be observed in muscovite clusters, indicating that this two-micas 
granitoid certainly derived from pelites that experienced an early metamorphic event.

Rounded apatites are often enclosed in the biotite and associated with small monazite grains.

\subsubsection{Textural observations of analyzed monazite grains}

Textural observations also suggest a mixing of two populations of small monazite grains (20$60 \mu \mathrm{m}$ ). Some monazite grains (population A) are enclosed in biotite (Fig. 18a), white mica or rarely K-feldspar. BSE pictures show either well rounded or anhedral shapes (Fig. 18a). BSE images also show sub-euhedral grains (population B), located at grain boundaries between biotite and feldspars or quartz (Fig. 18b). In some of these monazite grains, a chemical zonation with a light core and a dense rim can be observed (Fig. 18c), indicating that these hybrid grains (population $\mathrm{A}+\mathrm{B}$ ) probably show relics of population $\mathrm{A}$.

\subsubsection{Data sorting}

The analytical results plotted in $\mathrm{Th} / \mathrm{Pb}$ vs. U/Pb diagram (Fig. 18d), define a best fit line (thick solid line) that does not coincide with the theoretical isochron within its error envelope (thin solid line). However, two populations of data can be distinguished. A first one (black ellipses), clearly associated with old punctual ages, fitting with a $440 \mathrm{Ma}$ isochron (thick dashed line), shows low $\mathrm{U} / \mathrm{Pb}$ ratio $(<6.5)$ and high $\mathrm{Th} / \mathrm{Pb}$ ratio $(>25)$. A second population (grey ellipses) corresponding to younger punctual ages, clustering around a $410 \mathrm{Ma}$ isochron, is marked by a higher $\mathrm{U} / \mathrm{Pb}$ ratio $(>6)$ and a lower $\mathrm{Th} / \mathrm{Pb}$ ratio $(<30)$.

These two populations can also be represented in a U/Th vs. age diagram (Fig. 18e). In case of a single population of monazite, the U/Th ratio should be independent of time, since it is only controlled by substitution reactions that rule actinides incorporation (Bowie and Horne, 1953). These latter occur during grain crystallization associated with a single geological event. The best fit line of the whole data (dashed line) shows U/Th ratio decreasing with time. However under and above a particular value of U/Th $(0.23)$, the U/Th ratio seems to be more independent of time, with best fit lines (solid lines) less oblique than the best fit line of whole data. This threshold distinguishes two populations of monazite similar to those defined in $\mathrm{Th} / \mathrm{Pb}$ vs. $\mathrm{U} / \mathrm{Pb}$ diagram.

\subsubsection{Y203 content}

Yttrium (Y) content is relatively low $(<2 \%$ oxide weight $)$ in monazite that can incorporate this latter one through light REE substitution. As the amount of $\mathrm{Y}_{2} \mathrm{O}_{3}$ that can be integrated in rare earth phosphate highly depends on the environment crystallization of the monazite grain, this parameter can be used for characterizing multiple populations. Temperature but also garnet chemical behaviour can influence this parameter ([Foster et al., 2002] and [Pyle et al., 2001]).

When plotting $\mathrm{Y}_{2} \mathrm{O}_{3}$ amount and punctual ages (and their error bars) for each analysis (Fig. 18f), the same two populations can be distinguished. Population A shows for old ages an average value of $1.45 \%$ for $\mathrm{Y}_{2} \mathrm{O}_{3}$ content with some little fluctuations $(\sigma=0.44)$. Population $\mathrm{B}$ is marked by young ages and a higher $\mathrm{Y}_{2} \mathrm{O}_{3}$ average content $(2.05 \%)$ without significant scattering $(\sigma=0.16)$. $\mathrm{Y}_{2} \mathrm{O}_{3}$ variations can also be observed in zonation of hybrid grains (Fig. $18 \mathrm{~g}$ ), with low values in the core of the grain (corresponding to population $\mathrm{A}$ ) and high values in the rim (corresponding to population B).

\subsubsection{Results}


After sorting data according to their textural and chemical characteristics, populations $\mathrm{A}$ and $\mathrm{B}$ are plotted in separate $\mathrm{Th} / \mathrm{Pb}$ vs. U/Pb diagrams (Fig. 18h). For population $\mathrm{A}, 79$ punctual analyses on 25 grains (core and single grains) were performed and data well spread with large range of $\mathrm{U} / \mathrm{Pb}$ ratio $(2-10)$ and $\mathrm{Th} / \mathrm{Pb}$ ratio $(30-45)$, nicely constraining the best fit line (thick solid line). Theoretical isochron (dashed line) is equivalent to that latter one within the error envelope (thin solid line). As intercept ages match within the error bars (respectively $451+23 /-21 \mathrm{Ma}$ and $408+42 /-47 \mathrm{Ma}$ for $\mathrm{Th}-\mathrm{Pb}$ age and $\mathrm{U}-\mathrm{Pb}$ age) and since MSWD is lower than theoretical one (1.3 vs. 1.32), population A can be dated at $437 \pm 5 \mathrm{Ma}$.

The 40 analyses of $16 \mathrm{~B}$-type grains (rim and single grains) are clustered in $\mathrm{Th} / \mathrm{Pb} \mathrm{vs}$. U/Pb diagram with short range of $\mathrm{Th} / \mathrm{Pb}$ and $\mathrm{U} / \mathrm{Pb}$ ratios (respectively from 20 to 30 and from 7 to 10). Although it involves a bad constraint of the best fit line, a theoretical isochron is equivalent to that latter one within the error envelope. Intersect ages (respectively $454+63 /-50 \mathrm{Ma}$ and $373+46 /-59 \mathrm{Ma}$ for $\mathrm{Th}-\mathrm{Pb}$ age and $\mathrm{U}-\mathrm{Pb}$ age) and calculated MSWD (1.2 vs. 1.45 for theoretical MSWD) satisfy the validity criteria and B-type monazites thus yield an age of $412 \pm 5 \mathrm{Ma}$.

\subsection{Age significance}

These chemical and textural evidences show the existence of two distinctive populations of monazite. On one hand, a first Upper Ordovician event is represented by datings of sample WU227 and A-type monazites of sample WU816. In biotite gneisses, monazites have clearly a metamorphic origin. Those grains generally crystallize under amphibolite facies conditions, corresponding to metamorphic peak conditions or early portion of retrograde path ([Bingen et al., 1996] and [Foster et al., 2002]). In sample WU816, A-type monazites are anhedral grains or occur in core of hybrid grains. Those crystals can be thus considered as relict grains and were probably formed during a first metamorphic event. The age obtained for WU 227 agrees with the $421 \pm 8 \mathrm{Ma} \mathrm{Ar}-\mathrm{Ar}$ cooling age of biotite yielded by the Cizhu garnet-bearing anatectic granite located to the west (Fig. 6) (Shu et al., 1999).

On the other hand, a second Late Silurian-Early Devonian event can be inferred by dating Btype monazite of sample WU816. These grains occur as newly formed single grains or rim around relict grains. Many processes can be at the origin of those monazites. Diffusion of lead, thorium and uranium along the border of the grain has been described by Suzuki et al. (1994) and Smith and Giletti (1997). Incomplete dissolution and reprecipitation of pre-existing monazite can also occur under particular $P-T$ conditions (Kelsey et al., 2008). Hydrothermal weathering hypothesis can be eliminated as no significant chemical variations between both populations have been registered. For the other cases, an increase of temperature is needed, its duration and intensity controlling the width of the rim or the percentage of dissolved monazite. This increase of heat could be initiated by an anatectic episode that led to the formation of two-mica granitoids. According to Förster (1998), crystallization of monazite could thus occur during solidus crossing. As suggested by our observed textures and according to Bingen et al. (1996) and Pyle et al. (2001), destabilisation of magmatic apatite could emphasize B-type monazite crystallisation. Polyphase monazite has already been described by Simpson et al. (2000) who distinguished a barrovian stage followed by a re-heating stage for Himalayan monazites with the help of chemical data and mineralogical textures. Our study thus provided new data and good constraints for the timing of metamorphic and magmatic events in Wuyishan area.

\section{Discussion, geodynamic evolution}


The afore-mentioned data show that the Early Paleozoic orogeny in the studied area was accommodated by: (i) a south-directed deformation in the high grade units and weakly metamorphosed units located to the east of the Ganjiang Fault and to the south of the Jiangshan-Shaoxing Fault; (ii) a north or northwest-directed deformation in the units located to the west of Ganjiang Fault and to the north of Jiangshan-Shaoxing Fault. The latter area shows only a thin-skinned tectonics, affecting Sinian to Ordovician low grade (lower greenschist at maximum) meta-sediments to the west of Ganjiang Fault and non-metamorphic Sinian-Lower Paleozoic sedimentary strata to the north of Jiangshan-Shaoxing Fault, over a décollement level. The former area (Wuyishan proper) includes metamorphic units (up to amphibolite facies) affected by thick-skinned tectonics, responsible for crustal thickening. They may include ultramafic rocks, usually at the base, along the tectonic contact, like the Chencai peridotite, relict of mantle tectonite. The units made of mafic rocks exposed from Zhenghe to Jian'ou have been considered as possible Neo-proterozoic ophiolitic mélanges initially linked to the Yangtze-Cathaysia collision history (e.g. [Charvet, 1999], [Shu, 2006], [Shu et al., 2006] and [Wang and Shu, 2007]). However, recent data about the dating and geochemistry of those rocks lead to abandon this hypothesis. Their age is younger that the collision; thus they cannot represent a remnant of the oceanic domain separating the two blocks. They show various geochemical affinities but predominantly an alkaline one which, in addition to the presence of contemporaneous felsic rocks documenting a bimodal magmatism, indicate a rifting origin, linked with the Nanhua rift (e.g. [Li et al., 2005] and [Li et al., 2009a]). However, the association of basalts and well-bedded red cherts suggests that the rifting episode led to some deep-sea environment, even if the rift failed and did not reach the oceanic spreading stage. Such an active and intense rift-faulting, thinning the continental crust, may explain that the sub-continental mantle peridotite came locally to a shallow depth and could afterwards be involved in the thrusting during the compression phase.

The available chronological constraints give an age of around 850-800 Ma for the rifting stage, an age of $465 \mathrm{Ma}$ (Middle Ordovician) to about $445 \mathrm{Ma}$ (Late Ordovician) for the prograde metamorphism, followed by anatexis and granitic intrusions mainly from 445 to $430 \mathrm{Ma}$, up to $390 \mathrm{Ma}$. They also indicate that the Paleoproterozoic basement is involved in the tectonics.

The nappes are rooted to the north, between the Wuyishan and the Jiangnan belt; the root zone is now cut by the Jiangshan-Shaoxing Fault. It is not a Paleozoic suture zone as it does not correspond to the closure of an oceanic domain, but the trace of the continental subduction of the southern part of the Cathaysia Block beneath its northern part. The subduction likely initiated at the location of the former Nanhua rift. In order to emphasize the difference with an ophiolitic suture, the Jiangshan-Shaoxing Fault as been referred to as a "scar fault" (Faure et al., 2009).

We may tentatively reconstruct a geodynamic evolutionary model (Fig. 19).

During the Neo-proterozoic, around 850-800 Ma, the Nanhua rift was created (Fig. 19a). This event came after completion of the Jiangnan orogeny, which amalgamated the Yangtze and Cathaysia Blocks. The central part of the rift was deep enough for having a siliceous sedimentation above the alkaline pillow-lavas. The geochemistry of volcanic rocks argue against the oceanisation. It remained a Neo-proterozoic rift.

At ca. $465 \mathrm{Ma}$, after a long period of sedimentation, giving a pile of up to $7-8 \mathrm{~km}$, the compressional stage began and was accommodated by the underthrusting of the southern 
block beneath the northern one (Fig. 19b). The central part of the rift was involved in the south-directed deformation, with the thrusting of the deep sediments, the mantle peridotite, and some pieces of lower crust. To the north, where the sedimentary pile is usually thinner, the orogeny led to a NW-prograding turbidite basin, until the Silurian (Rong et al., 2003, 2009).

At 440-430 Ma (Fig. 19c), the tectonic piling was followed by anatexis and post-tectonic emplacement of granites, mainly peraluminous ( $\underline{\operatorname{Sun}, 2006)}$. It was also the time of a general doming of the South China Block, between 435 and $425 \mathrm{Ma}$ ([Wan, 2003] and [Sun et al., 2006]). The N-S alignment of the granitic plutons suggests en-échelon bodies, possibly corresponding to a sinistral transpression. We tentatively argue for the sinistral motion of NEtrending faults like the Ganjiang Fault. This fault, known as an important crustal one according to geophysical data, had a documented left-lateral motion in the Early Cretaceous (Deng et al., 2000). As a hypothesis, we suggest that a precursor of this fault was active at the end of the Early Paleozoic orogeny. That could explain why the northward-deformed Jinggangshan domain, weakly metamorphosed, is in sharp contact with the high grade western part of Wuyishan. This "outer" zone was initially more to the north. Similarly, the Jiangshan-Shaoxing Fault, a major one at lithospheric scale ([Xiong and Liu, 2000] and [Zhang et al., 2005]), was later responsible for the dextral offset of the "outer" YushanJiangshan area, now in front of the Yongping-Longyou metamorphic domain. The age of displacement is unknown; only a poorly reliable age of $355 \mathrm{Ma}$ has been obtained, by $\mathrm{K}-\mathrm{Ar}$ method on muscovite (Xu et al., 1994). The presence of such deep-seated sinistral faults: Ganjiang Fault and some others like the Wuyishan-Taining Fault could have helped some melting at the base of the crust. But this hypothesis remains to be tested.

The Lower Paleozoic belt, in the Wuyishan area, in agreement with our preliminary work in western Jiangxi (Faure et al., 2009), is a pre-Devonian intracontinental orogen, which does not correspond to the closure of an oceanic realm but of a rift, by intracontinental subduction. The Jiangshan-Shaoxing Fault is not a Paleozoic suture zone. Indeed, along this fault: (1) there is no ophiolite suite, (2) calc-alkaline magmatism indicating an oceanic subduction during the Early Paleozoic is absent and (3) the granitoids emplaced during the Early Paleozoic do not suggest a continental margin setting (Sun, 2006). Two of them were interpreted as generated by dehydration melting of Proterozoic crust during the relaxation phase of the pre-Devonian orogeny ( $\mathrm{Li}$ et al., 2009b). Devoid of ophiolites, arc magmatism, and HP metamorphic rocks, this orogen shows some similarities with the European Pyrenean Chain ([Roure et al., 1989], [Garcia-Senz et al., 2000] and [Beaumont et al., 2000]), but with a marked asymmetry. The deep-seated tectonics is restricted to the southern side, the northern side showing only thin-skinned tectonics.

The Jiangshan-Shaoxing Fault is regarded by some authors as a Proterozoic suture zone (e.g., Zhou and Zhu, 1993), corresponding to the definitive welding of Yangtze and Cathaysia Blocks and forming the South China continent. However, alternative hypotheses have been proposed, implying a Mesozoic collision in SE China ([Hsü et al., 1988], [Hsü et al., 1990] and [Xiao and He, 2005]). The hypothesis of a Mesozoic alpine-type collision advocated by (Hsü et al., 1988) and (Hsü et al., 1990), has been questioned by several authors pointing out the contradiction with field data (e.g. [Rowley et al., 1989], [Gupta, 1989] and [Charvet et al., 1996]). Since 1988, many papers argued against this interpretation, pointing out serious discrepancies with the field observations. For instance, the Banxi Group interpreted as a Mesozoic mélange by Hsü et al. (1990), appearing as tectonic windows beneath nappes of Paleozoic material, has been confirmed to be Proterozoic (e.g. [Wang et al., 2007] and [Zhang 
et al., 2008]). The hypothesis of an Early Mesozoic collision proposed by Xiao and He (2005) was based on an interpretation of sedimentary sequences suggesting two deep-sea basins extrapolated as two Triassic oceanic domains in the Yiyang-Shexian and Jiangshan-Shaoxing areas. But, in addition to the lack of any Mesozoic remnant of oceanic crust, the careful examination of the paleogeography of these areas shows that they were not even in a deep-sea environment but in a shallow-sea or littoral one during the Late Paleozoic-Early Mesozoic ([Shu et al., 2006] and [Shu et al., 2008a]). The presumed Upper Paleozoic-Triassic cherts and siliceous shales yielded Proterozoic acritarchs ([Yang et al., 2005], [Wang et al., 2006], [Shu et al., 2006] and [Shu et al., 2008a])! The features commonly present and expected in a collisional belt (Early Mesozoic ophiolites, HP metamorphic rocks, arc volcanics, mélanges, etc.) are missing in this region. They are Proterozoic, as already stated.

In addition, the paleomagnetic data show that during the Early Triassic (before the Indosinian event) the Yangtze and Cathaysia Blocks were welded (Tan et al., 2000).

Therefore, the hypothesis of a Triassic or Jurassic collision with oceanic closures is not documented but contradicted by many robust data. It does not mean that a Mesozoic tectonic deformation did not occur. Of course, it took place and affected up to the Upper Jurassic strata, with a northern vergence in NW Zhejiang (Xiao and He, 2005). Conversely, the Indosinian deformation induced also south-verging structures in the Jiulingshan (e.g. Shu et al., 2008a).

The Lower Paleozoic belt was not due to a collision after an oceanic subduction stage but to the compression of a rift which developed after the welding of Yangtze and Cathaysia Blocks in a single continent during the Neo-proterozoic.

\section{Conclusions}

In the Wuyishan and surrounding areas, prior to the Devonian unconformity, an Ordovician tectonic event was responsible for: (i) south-directed structures in the Wuyishan proper and its southern border, related to both thin-skinned and thick-skinned tectonics, accompanied by metamorphism and crustal thickening and (ii) north-directed structures to the west of Ganjiang Fault and north of Jiangshan-Shaoxing Fault, where only thin-skinned tectonics is visible.

The shortening was accommodated by the southward emplacement of thrust sheets, involving deep crustal material and some mantle peridotite, and likely repetition of continental material, both responsible for crustal thickening.

The orogeny was due to the underthrusting of the southern part of the Cathaysia block beneath its northern part, closing the pre-existing Nanhua rift, created at around 850-800 Ma. The rift was likely a line of weakness inducing the place of underthrusting; most of the rift sedimentary fill was involved in the southward thrusting.

The syn-metamorphic tectonic event was followed by anatexis and granite emplacement at around 440-430 Ma. New age data from monazite (433, $437 \mathrm{Ma}$ ) confirm this timing of metamorphism and anatexis and suggest an exhumation process lasting until Early Devonian (412 Ma).

This Lower Paleozoic belt is an intracontinental orogen, without oceanic suture zone, showing some similarities with the European Pyrénées Chain, but with a strong asymmetry. 


\section{Acknowledgements}

Constructive comments by reviewers Zheng-Xiang Li and Jun Gao improved the manuscript. We acknowledge the financial supports provided by Institut des Sciences de la Terre d'Orléans (ISTO) for this study. Field work was supported by National Natural Science Foundation of China (No. 40634022) and the State Key Laboratory for Mineral Deposits Research of Nanjing University (No. 2008-I-01).

\section{References}

Beaumont et al., 2000 C. Beaumont et al., Factors controlling the Alpine evolution of the central Pyrenees inferred from a comparison of observations and geodynamical models, Journal of Geophysical Research - Solid Earth 105 (B4) (2000), pp. 8121-8145.

Bingen et al., 1996 B. Bingen, D. Demaiffe and J. Hertogen, Redistribution of rare earth elements, thorium, and uranium over accessory minerals in the course of amphibolite to granulite facies metamorphism; the role of apatite and monazite in orthogneisses from southwestern Norway, Geochimica et Cosmochimica Acta 60 (8) (1996), pp. 1341-1354.

Bowie and Horne, 1953 S.H.U. Bowie and J.E.T. Horne, Cheralite, a new mineral of the monazite group, Mineralogical Magazine 30 (221) (1953), pp. 93-99.

Carter et al., 2001 A. Carter, D. Roques, C. Bristow and P. Kinny, Understanding Mesozoic accretion in Southeast Asia: significance of Triassic thermotectonism (Indosinian orogeny) in Vietnam, Geology 29 (3) (2001), pp. 211-214.

Chang, 1996 E.Z. Chang, Collisional orogene between north and south China and its eastern extension in the Korean Peninsula, Journal of Southeast Asian Earth Sciences 13 (3-5) (1996), pp. 267-277.

Charvet, 1999 J. Charvet, D. Cluzel, M. Faure, M. Caridroit, L.S. Shu and H.F. Lu, Some tectonic aspects of the pre-Jurassic accretionary evolution of East Asia. In: I. Metcalfe, J.S. Ren, J. Charvet and S. Hada, Editors, Gondwana Dispersion and Asian Accretion, IGCP 321 Final Results Volume, Balkema (1999), pp. 37-65.

Charvet et al., 1996 J. Charvet, L.S. Shu, Y.S. Shi, L.Z. Guo and M. Faure, The building of South China: collision of Yangtzi and Cathaysia blocks, problems and tentative answers, Journal of Southeast Asian Earth Sciences 13 (1996), pp. 223-235.

Chen et al., 1991 J. Chen, K. Foland, F. Xing, X. Xu and T. Zhou, Magmatism along the southeast margin of the Yangtze Block. Precambrian collision of the Yangtze and Cathaysia Blokcs of China, Geology 19 (1991), pp. 815-818.

Chen et al., 2008 C.H. Chen, C.Y. Lee, P.S. Hsieh, W. Zeng and H. Zhou, Approaching the age problem for some metamorphosed Precambrian basement rocks and phanerozoic granitic bodies in the Wuyishan area: application of the EMP monazite age dating, Geological Journal of China Universities 14 (1) (2008), pp. 1-15

Chen et al., 2009 Z.H. Chen, K.Y. Guo, Y.G. Dong, R.G. Chen, L.M. Li, Y.H. Liang, C.H. Li, X.M. Yu, L. Zhao and G.F. Xing, Possible early Neoproterozoic magmatism associated with 
slab window in the Pingshui segment of the Jiangshan-Shaoxing suture zone: evidence from zircon LA-ICP-MS U-Pb geochronology and geochemistry, Science in China (D) 52 (7) (2009), pp. 925-939 10.1007/s11430-009-0071-6.

Cluzel et al., 1991 D. Cluzel, L. Jolivet and J.P. Cadet, Early Middle Paleozoic intraplate orogeny in Ogcheon belt (South Korea). A new insight on the Palezoic build-up of east Asia, Tectonics 10 (1991), pp. 1130-1151.

Cocherie and Albarède, 2001 A. Cocherie and F. Albarède, An improved U-Th-Pb age calculation for electron microprobe dating of monazite, Geochimica et Cosmochimica Acta $\mathbf{6 5}$ (2001), pp. 4509-4522.

Cocherie et al., 1998 A. Cocherie, O. Legendre, J.J. Peucat and A.N. Kouamelan, Geochronology of polygenetic monazites constrained by in situ electron microprobe Th-Utotal lead determination; implications for lead behaviour in monazite, Geochimica et Cosmochimica Acta 62 (14) (1998), pp. 2475-2497.

Cocherie et al., 2005 A. Cocherie, E.B. Mezeme, O. Legendre, C.M. Fanning, M. Faure, P. Rossi, M.L. Williams and R.J. Tracy, Electron-microprobe dating as a tool for determining the closure of Th-U-Pb systems in migmatitic monazite, American Mineralogist, Mineralogical Society of America, Washington (2005), pp. 607-618.

Deng et al., 2000 P. Deng, L.S. Shu, M.G. Yang, Y.J. Guo and X.Q. Yu, Geological features and dynamic evolution of the Ganjiang Fault in Jiangxi Province, Geological Review 49 (2) (2000), pp. 113-122 (in Chinese with English abstract).

Faure et al., 2009 M. Faure, L.S. Shu, B. Wang, J. Charvet, F. Choulet and P. Monié, Intracontinental subduction: a possible mechanism for the Early Palaeozoic Orogen of SE China, Terra Nova (2009) 10.1111/j.1365-3121.2009.00888.

FBGMR, 1985 FBGMR (Fujian Bureau of Geology and Mineral Resources), 1985. Regional Geology of Fujian Province. Geological Publishing House, Beijing, China, 671 p (in Chinese with English abstract).

Förster, 1998 H.J. Förster, The chemical composition of REE-Y-Th-U-rich accessory minerals in peraluminous granites of the Erzgebirge-Fichtelgebirge region, Germany; part I, the monazite (Ce)-brabantite solid solution series, American Mineralogist 83 (1998), pp. $1302-1315$.

Foster et al., 2002 G. Foster, H.D. Gibson, R. Parrish, M. Horstwood, J. Fraser and A. Tindle, Textural, chemical and isotopic insights into the nature and behaviour of metamorphic monazite, Chemical Geology 91 (2002), pp. 183-207.

Gan et al., 1993 X. Gan, H. Li, D. Sun and J. Zhuang, Geochronology of the Precambrian basement in northern Fujian, Geology of Fujian 12 (1) (1993), pp. 17-32 (in Chinese with English abstract).

Gan et al., 1995 X. Gan, H. Li, D. Sun, W. Jin and F. Zhao, A geochronological study on early Proterozoic granitic rocks, southeastern Zhejiang, Acata Petrologica et Mineralogica 14 (1) (1995), pp. 1-8 (in Chinese with English abstract). 
Gan et al., 1996 X.C. Gan, F.Q. Zhao, W.S. Jin and D.Z. Sun, The U6Pb ages of Early Proterozoic-Archean zircons captured by igneous rocks in southern China, Geochimica 25 (2) (1996), pp. 112-120 (in Chinese).

Gao et al., 2009 J. Gao, R. Klemd, L.G. Long, X.M. Xiong and Q. Qian, Adakitic signature formed by fractional crystallization: an interpretation for the Neo-Proterozoic metaplagiogranites of the NE Jiangxi ophiolitic mélange belt, South China, Lithos 110 (2009), pp. 277-293.

Garcia-Senz et al., 2000 J. Garcia-Senz, J.A. Muñoz and K. McClay, Inversion of Early Cretaceous extensional basins in the central Spanish Pyrenees, AAPG Bulletin 84 (9) (2000), pp. 1428-1429.

Gilder et al., 1991 S. Gilder, G.R. Keller, M. Luo and X.X. Zhao, Eastern Asia and the western Pacific timing and spatial distribution of rifting in China, Tectonophysics 197 (1991), pp. 225-243.

Grabau, 1924 Grabau, A., 1924. Stratigraphy of China, part I, Paleozoic and older, Geol. Surv. of Agric. and Commerce, Peking.

Guo et al., 1985 L.Z. Guo, Y.S. Shi, R.S. Ma, H.F. Lu, S. Ye, Y. Ding, S. Chen and B. Xia, Plate movement and crustal evolution of the Jiangnan Proterozoic mobile belt, Southeast China, Earth Science (Chikyu Kagaku) 39 (2) (1985), pp. 156-166.

Guo et al., 1989 L.Z. Guo, Y.S. Shi, H.F. Lu, R.S. Ma and H. Dong, The pre-Devonian tectonic patterns and evolution of South China, Journal of Asian Earth Sciences 3 (1989), pp. 87-93.

Gupta, 1989 S. Gupta, Comments on "Overthrust tectonics in South China", Geology 17 (1989), pp. 669-671.

HBGMR, 1988 HBGMR (Hunan Bureau of Geology, Mineral Resources), Regional Geology of Hunan Province, Geological Publishing House, Beijing (1988) 726 p.

Hsü et al., 1988 K.J. Hsü, S. Sun, J.L. Li, H.H. Chen, H.P. Peng and A.M.C. Sengör, Mesozoic overthrust tectonics in South China, Geology 16 (1988), pp. 418-421.

Hsü et al., 1990 K.J. Hsü, J. Li, H.H. Chen, Q. Wang, S. Sun and A.M.C. Sengör, Tectonics of South China: key to understanding West pacific geology, Tectonophysics 183 (1990), pp. 9-39.

Hu et al., 1991 Hu, X., Xu, J., Tong, C., Chen, C., 1991. The Precambrian Geology of Southwestern Zhejiang Province. Geological Publishing House, Beijing, 278 p (in Chinese with English abstract).

Hu et al., 1992 X. Hu, J. Xu, C. Chen, C. Li and H. Li, Single-grain zircon U-Pb ages for the early Proterozoic granite and pegmatite from southwestern Zhejiang, Chinese Science Bulletin 37 (11) (1992), pp. 1016-1018 (in Chinese with English abstract). 
Huang, 1978 T.K. Huang, An outline of the tectonic characteristics of China, Eclogae Geologicae Helvetiae 71 (1978), pp. 611-635.

Huang et al., 1980 J. Huang, J. Ren, C. Jiang, Z. Zhang and D. Qin, The Tectonic Evolution of China, Science Press, Beijing (1980) 124 p.

Jahn et al., 1990 B.M. Jahn, X.H. Zhou and J.L. Li, Formation and tectonic evolution of southeastern China and Taiwan: isotopic and geochemical constraints, Tectonophysics 183 (1990), pp. 145-160.

JBGMR, 1984 JBGMR (Jiangxi Bureau of Geology and Mineral Resources), 1984. Regional Geology of Jiangxi Province. Geological Publishing House, Beijing, 921 p (in Chinese with English abstract).

Kelsey et al., 2008 D.E. Kelsey, C. Clark and M. Hand, Thermobarometric modelling of zircon and monazite growth in melt-bearing systems; examples using model metapelitic and metapsammitic granulites, Journal of Metamorphic Geology 26 (2008), pp. 199-212

Kim et al., 2006 S.W. Kim, C.W. Oh, I.S. Williams, D. Rubatto, L.C. Ryu, V.J. Rajesh, C.B. Kim, J. Guo and M. Zhai, Phanerozoic high-pressure eclogite and intermediate-pressure granulite facies metamorphism in the Gyeonggi Massif, South Korea: implications for the eastward extension of the Dabie-Sulu continental collision zone, Lithos 92 (3-4) (2006), pp. 357-377.

Kong et al., 1995 Kong, X.S., Li, Z.F., Feng, C.G., Gu, M.G., Ma, M.P., 1995. The Precambrian Geology of Chencai region in Zhejiang Province. Geological Publishing House, Beijing, 921 p (in Chinese with English abstract).

Lepvrier et al., 2008 C. Lepvrier, V.V. Nguyen, H. Maluski, T.T. Phan and V.V. Tich, Indosinian tectonics in Vietnam, C.R. Geoscience 340 (2008), pp. 94-111.

$\underline{\mathrm{Li}, 1988}$ G.K. Li, A discussion on the basement rocks in Fujian Province, Fujian Geology 7 (1988), pp. 80-118.

Li, 1989 G.K. Li, Isotopic ages of the basement rocks in Fujian Province and their implications for the regional tectonic evolution, Fujian Geology 8 (1989), pp. 159-168 (in Chinese).

Li, 1993 J.L. Li, Tectonic framework and evolution of southeastern China, Journal of Southeast Asian Earth Sciences 8 (1993), pp. 219-223.

$\underline{\mathrm{Li}, 1997}$ X.H. Li, Timing of the Cathaysia Block formation: constraints from SHRIMP U-Pb zircon geochronology, Episodes 20 (3) (1997), pp. 188-192.

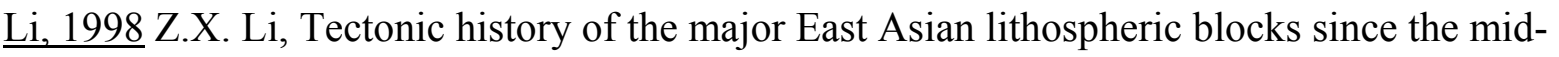
Proterozoic - a synthesis. In: M.J. Flower, S.L. Chung, C.H. Lo and T.Y. Lee, Editors, Mantle Dynamics and Plate Interactions in East Asia. Geodynamics Series vol. 27, American Geophysical Union, Washington, DC, United States (1998), pp. 221-243. 
Li and Mooney, $1998 \mathrm{~S}$. Li and W.D. Mooney, Crustal structure of China from deep seismic sounding profiles, Tectonophysics 288 (1998), pp. 105-113

Li et al., 1989 X.H. Li, M. Tatsumoto, W.R. Premo and X. Gui, Age and origin of the Tanghu granite, southeast China: results from $\mathrm{U}-\mathrm{Pb}$ single zircon and $\mathrm{Nd}$ isotopes, Geology 17 (5) (1989), pp. 395-399.

Li et al., 1993 S.G. Li, Y.H. Nie, N.J. Ge, D.L. Liu and J.X. Hu, Trace element geochemistry of volcanic rocks of Badu Group in the West of Zhejiang: a possible Early Proterozoic ophiolitic belt and the tectonic implications. In: J.L. Li, Editor, Crustal Structure and Geochemical Evolution of the Southeast Continents, Publishing House of Metallurgy and Industry (1993), pp. 98-117 (in Chinese).

Li et al., 2002 Z.X. Li, X.H. Li, H.W. Zhou and P.D. Kinny, Grenvillian continental collision in South China: new SHRIMP U-Pb zircon results and implications for the configuration of Rodinia, Geology 30 (2) (2002), pp. 163-166

Li et al., 2003a X.H. Li, Z.X. Li, W.C. Ge, H.W. Zhou, W.X. Li, Y. Liu and T.D. Wingate, Neoproterozoic granitoids in South China: crustal melting above a mantle plume at ca. 825 Ma?, Precambrian Research 122 (1-4) (2003), pp. 45-83.

Li et al., 2003b Z.X. Li, X.H. Li, P.D. Kinny, J. Wang, S. Zhang and H. Zhou, Geochronology of Neoproterozoic syn-rift magmatism in the Yangtze Craton, South China and correlations with other continents: evidence for a mantle plume that broke up Rodinia, Precambrian Research 122 (1-4) (2003), pp. 85-109.

Li et al., 2005 W.X. Li, X.H. Li and Z.X. Li, Neoproterozoic bimodal magmatism in the Cathaysia Block of South China and its tectonic significance, Precambrian Research 136 (1) (2005), pp. 51-66.

Li et al., 2007 Z.X. Li, J.A. Wartho, S. Occhipinti, C.L. Zhang, X.H. Li, J. Wang and C. Bao, Early history of the eastern Sibao Orogen (South China) during the assembly of Rodinia: new mica 40Ar/39Ar dating and SHRIMP U-Pb detrital zircon provenance constraints, Precambrian Research 159 (2007), pp. 79-94.

Li et al., 2008 X.H. Li, W.X. Li, Z.X. Li and Y. Liu, 850-790 Ma bimodal volcanic and intrusive rocks in northern Zhejiang, South China: a major episode of continental rift magmatism during the breakup of Rodinia, Lithos 102 (2008), pp. 341-357.

Li et al., 2009a X.H. Li, W.X. Li, Z.X. Li, C.H. Lo, J. Wang, M.F. Ye and Y.H. Yang, Amalgamation between the Yangtze and Cathaysia Blocks in South China: constraints from SHRIMP U-Pb zircon ages, geochemistry and Nd-Hf isotopes of the Shuangxiwu volcanic rocks, Precambrian Research 174 (2009), pp. 117-128.

Li et al., 2009b Z.X. Li, X.H. Li, J.A. Wartho, C. Clark, W.X. Li, C.L. Zhang and C. Bao, Magmatic and metamorphic events during the early Paleozoic Wuyi-Yunkai orogeny, southeastern South China: new age constraints and pressure-temperature conditions, Geological Society of America Bulletin (2009) 
Ludwig, 2003 Ludwig, K.R., 2003. User's Manual for Isoplot 3.00. A Geochronological Toolkit for Microsoft Excel. Berkeley Geochronology Center, 70 p.

Ma, 2006 R. Ma, New thought about the tectonic evolution of the South China: with discussion on several problems of the Cathaysian Old land, Geological Journal of China Universities 12 (2006), pp. 448-456.

Mamberti, 1996 Mamberti, M., 1996. Etude microstruturale et pétro-géochimique du Wuyi Shan (Fujian et Zhejiang, Chine Sud-Est). Unpublished Master Dissertation, Orléans University, $52 \mathrm{p}$.

Montel et al., 1996 J.-M. Montel, S. Foret, M. Veschambre, C. Nicollet and A. Provost, Electron microprobe dating of monazite, Chemical Geology 131 (1-4) (1996), pp. 37-53.

Nagy et al., 2001 E.A. Nagy, H. Maluski, C. Lepvrier, U. Scharer, P.T. Thi, A. Leyreloup and V.V. Thich, Geodynamic significance of the Kontum massif in central Vietnam: composite 40Ar/39Ar and U-Pb ages from Paleozoic to Triassic, Journal of Geology 109 (6) (2001), pp. $755-770$.

Pommier et al., 2002 Pommier, A., Cocherie, A., Legendre, O., 2002. EPMA Dating User's Manual: Age Calculation from Electron Probe Microanalyser Measurements of $\mathrm{U}-\mathrm{Th}-\mathrm{Pb}$. BRGM Document, 9 p.

Pyle et al., 2001 J.M. Pyle, F.S. Spear, R.L. Rudnick and W.F. McDonough, Monazitexenotime-garnet equilibrium in metapelites and a new monazite-garnet thermometer, Journal of Petrology 42 (11) (2001), pp. 2083-2107.

$\underline{\text { Ren, } 1964}$ J.S. Ren, A preliminary study on pre-Devonian geotectonic problems of southeastern China, Acta Geologica Sinica 44 (4) (1964), pp. 418-431.

Ren, 1991 J.S. Ren, On the geotectonics of southern China, Acta Geologica Sinica 4 (2) (1991), pp. 111-130.

Ren and Chen, $1989 \mathrm{~J}$. Ren and T. Chen, Tectonic evolution of the continental lithosphere in eastern China and adjacent areas, Journal of Southeast Asian Earth Sciences 3 (1989), pp. 1727.

Ren et al., 1986 J. Ren, T. Chen, Z. Liu, B. Niu and F. Liu, Some problems on the tectonics of South China, Kexue Tongbao 3 (11) (1986), pp. 751-754.

Ren et al., 1987 J. Ren, C. Jiang, Z. Zhang and D. Qin, Geotectonic Evolution of China, Science Press, Beijing (1987) 203 p.

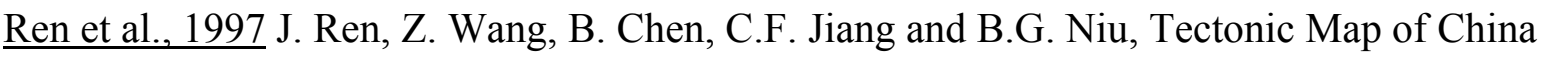
and Adjacent Regions, Geological Publishing House (1997) Scale 1:5000000.

Roger et al., 2007 F. Roger, H. Maluski, A. Leyreloup, C. Lepvrier and P.T. Thi, U-Pb dating of high temperature metamorphic episodes in the Kon Tum Massif (Vietnam), Journal of Asian Earth Sciences 30 (3-4) (2007), pp. 565-572. 
Rong et al., 2003 J. Rong, X. Chen, Y. Su, Y. Ni, R. Zhan, T. Chen, L. Fu, R. Li and J. Fan, Silurian Paleogeography of China. In: E. Landing and M. Johnson, Editors, Silurian Lands and Seas, New York State Museum Bulletin vol. 493 (2003), pp. 243-298.

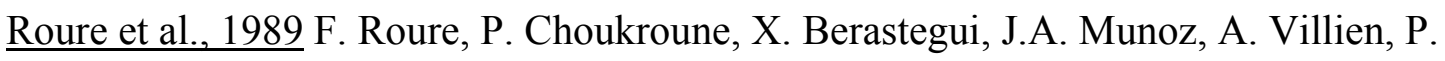
Matheron, M. Bareyt, M. Séguret, P. Camara and J. Deramond, ECORS Deep seismic data and balanced cross sections: geometric constraints on the evolution of the Pyrénées, Tectonics 8 (1989), pp. 41-50

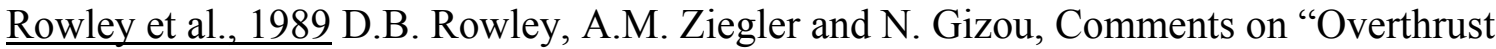
tectonics in South China", Geology 17 (1989), pp. 384-386.

$\underline{\text { Shu, } 2006}$ L.S. Shu, Predevonian tectonic evolution of South China: from Cathaysian Block to Caledonian folded orogenic belt, Geological Journal of China Universities 12 (4) (2006), pp. 418-431 (in Chinese with English abstract).

Shu and Charvet, 1996 L.S. Shu and J. Charvet, Kinematics and geochronology of the Proterozoic Dongxiang-Shexiang ductile hear zone with HP metamorphism and ophiolitic mélange (Jiangnan Region, China), Tectonophysics 267 (1996), pp. 291-302.

Shu et al., 1994 L.S. Shu, G.Q. Zhou, Y.S. Shi and J. Yin, Study of the high pressure metamorphic blueschist and its Neoproterozoic age in the Eastern Jiangnan belt, Chinese Science Bulletin 39 (14) (1994), pp. 1200-1204.

$\underline{\text { Shu et al., } 1999}$ L.S. Shu, H.F. Lu, D. Jia, J. Charvet and M. Faure, Study of the 40Ar/39Ar isotopic age for the early Paleozoic tectonothermal event in the Wuyishan region, S, China. Journal of Nanjing University 35 (1999), pp. 668-674.

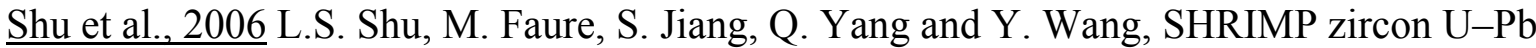
age, litho- and biostratigraphic analyses of the Huaiyu Domain in South China, Episodes 29 (2006), pp. 244-252.

Shu et al., 2008a L.S. Shu, M. Faure, B. Wang, X.M. Zhou and B. Song, Late PalaeozoicEarly Mesozoic geological features of South China: Response to the Indosinian collision events in Southeast Asia, C.R. Geoscience 340 (2008), pp. 151-165.

Shu et al., 2008b L.S. Shu, J.H. Yu, D. Jia, B. Wang, W. Shen and Y.Q. Zhang, Early Palaeozoic orogenic belt in the eastern segment of South China, Geological Bulletin of China 27 (2008), pp. 1581-1593.

Shu et al., 2008c L.S. Shu, P. Deng, J.H. Yu, Y.B. Wang and S.Y. Jiang, The age and tectonic environment of the rhyolitic rocks on the western side of Wuyi Mountain, South China, Science in China (D) 51 (8) (2008), pp. 1053-1063

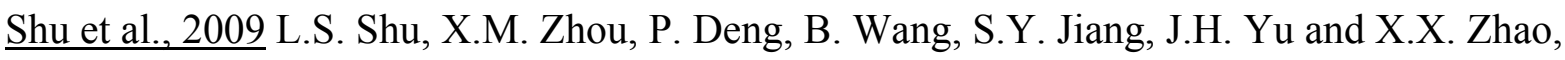
Mesozoic tectonic evolution of the southeast China block: New insights from basin analysis, Journal of Asian Earth Sciences 34 (2009), pp. 376-391.

Shui et al., 1986 T. Shui, B.T. Xu, R.H. Liang and Y.S. Qiu, Shaoxing-Jiangshan deep-seated fault zone, Zhejiang Province, Chinese Science Bulletin 31 (18) (1986), pp. 1250-1255. 


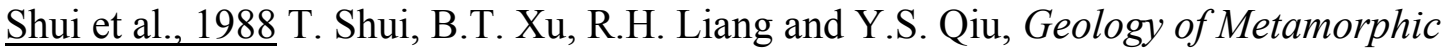
Basement in Zhejiang-Fujian Region, China, Science Press, Beijing (1988) pp. 1-94 (in Chinese).

Simpson et al., 2000 R.L. Simpson, R.R. Parrish, M.P. Searle and D.J. Waters, Two episodes of monazite crystallization during metamorphism and crustal melting in the Everest region of the Nepalese Himalaya, Geology 28 (5) (2000), pp. 403-406

Smith and Giletti, 1997 H.A. Smith and B.J. Giletti, Lead diffusion in monazite, Geochimica et Cosmochimica Acta 61 (5) (1997), pp. 1047-1055.

Stipp et al., 2002 M. Stipp, H. Stünitz, R. Heilbronner and S.M. Schmid, The eastern Tonale Fault Zone: a "natural laboratory" for crystal plastic deformation of quartz over a temperature range from 250 to $700{ }^{\circ} \mathrm{C}$, Journal of Structural Geology 24 (2002), pp. 1861-1884

$\underline{\text { Sun, } 2006}$ T. Sun, distribution of granites from South China and its petrogenesis, Geochimica et Cosmochimica Acta 70 (18, Suppl. 1) (2006), p. A626.

Sun et al., 2006 W.D. Sun, X. Ding and Y.H. Hu, Silurian large scale uplifting in South China: an aborted plume?, Geochimica et Cosmochimica Acta 70 (18, Suppl. 1) (2006), p. A627.

Suzuki and Adachi, 1991 K. Suzuki and M. Adachi, The chemical Th-U-total Pb isochron ages of zircon and monazite from the gray granite of the Hida Terrane, Japan, Journal of Earth Sciences, Nagoya University 38 (1991), pp. 11-37.

Suzuki et al., 1994 K. Suzuki, M. Adachi and I. Kajizuka, Electron microprobe observations of $\mathrm{Pb}$ diffusion in metamorphosed detrital monazites, Earth and Planetary Science Letters 128 (3-4) (1994), pp. 391-405.

Tan et al., 2000 X.D. Tan, K.P. Kodama, P.G. Wang and D.J. Fang, Palemagnetism of early Triassic limestones from the Huanan Block, South China: no evidence for the separation between the Huanan and Yangtze blocks during the Early Mesozoic, Geophysical Journal International 142 (1) (2000), pp. 241-256.

Wan, 2003 Wan, T.F., 2003. In: Wan, T.F. (Ed.), The Geotectonic Essentials of China, pp. $79-80$.

Wan et al., 2007 Y. Wan, D. Liu, M. Xu, J. Zhuang, B. Song, Y. Shi and L. Du, SHRIMP U$\mathrm{Pb}$ zircon geochronology and geochemistry of metavolcanic and metasedimentary rocks in NW Fujian, Cathaysian block, China: tectonic implications and the need to redefine lithostratigraphic units, Gondwana Research 12 (1-2) (2007), pp. 166-183.

Wang and Li, 2003 J. Wang and Z.X. Li, History of Neoproterozoic rift basins in South China: implications for Rodinia break-up, Precambrian Research 122 (1-4) (2003), pp. 141158.

Wang and Shu, 2007 M. Wang and L.S. Shu, Rock geochemical characteristics of the Neoproterozoic Wuyishan ophiolite mélange, Geology in China 34 (4) (2007), pp. 572-583 (in Chinese with English abstract). 
Wang et al., 1988 X. Wang, S.F. Yang, J.N. Shi, L.Z. Guo, Y.S. Shi, H.F. Lu, H.G. Dong, J.K. $\mathrm{Xu}, \mathrm{H} . \mathrm{N}$. Kong and X.J. Hu, Discovery of collision mélange in Longquan, Zhejiang Province and its significance for siuding collision orogenic belt in southeastern China, Journal of Nanjing University (Natural Sciences) 24 (3) (1988), pp. 367-378 (in Chinese with English abstract).

Wang et al., 2006 Y.J. Wang, Q. Yang, L.M. Yin, L.S. Shu, F.S. Lou and B. Wang, The putative "radiolarian cherts" from ophiolitic and metamorphic complexes in northeastern Jiangxi: a re-examination, Geological Journal of China Universities 12 (2006), pp. 98-105.

Wang et al., 2007 Y.J. Wang, W.M. Fan, G.C. Zhao, S.C. Ji and T.P. Peng, Zircon U-Pb geochronology of gneisses in Yunkai Mountains and its implications on the Caledonian event in South China, Gondwana Research 12 (4) (2007), pp. 404-416.

Wang et al., 2008 L.J. Wang, J.H. Yu, S.Y. O’Reilly, W.L. Griffin, Z.Y. Wei, S.Y. Jiang and $\mathrm{T}$. Sun, Grenvillian orogeny in the Southern Cathaysia Block: Constraints from U-Pb ages and $\mathrm{Lu}-\mathrm{Hf}$ isotopes in zircon from metamorphic basement, Chinese Science Bulletin 53 (19) (2008), pp. 3037-3050.

Xiang et al., 2008 H. Xiang, L. Zhang, W. Zhou, Z. Zhong, W. Zheng, R. Liu and S. Ting, Zircon U-Pb chronologic and Hf isotopic studies on basic-ultrabasic metamorphic basement of southwest Zhejiang: response of Hua-Xia (Cathaysia) metamorphic basement to Indosinian orogeny in Huanan (South China), Science in China (D) 38 (4) (2008), pp. 401-413 (in Chinese).

$\underline{X i a o}$ and He, 2005 W.J. Xiao and A.Q. He, Early Mesozoic thrust tectonics of the northwest Zhejiang region (Southeast China), Geological Society of America Bulletin 117 (7-8) (2005), pp. 945-961.

Xiong and Liu, 2000 S.B. Xiong and H.B. Liu, Crust-mantle structure of Zhejiang-Anhui Region and the boundary between Yangzi Block and Huanan Block, Progress in Geophysics 15 (4) (2000), pp. 3-17.

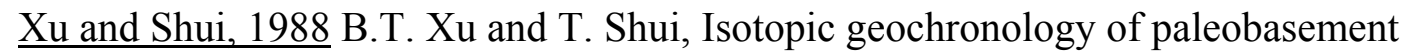
metamorphic rocks in Zhejiang and Fujian Provinces, Jiangxi Geology 2 (1988), pp. 16-17 (in Chinese).

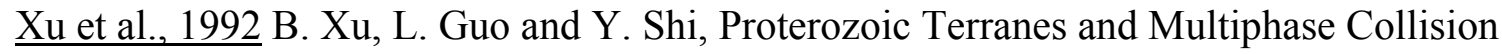
Orogens in Anhui-Zhejiang-Jiangxi Areas, Geol. Publishing House, Beijing (1992) 112 p.

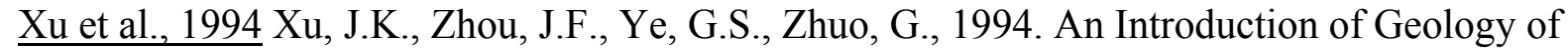
tge Gold Deposits in Shaoxing-Suichang Region, Zhejiang Province: Report of the Department of Geology and Mineral Resources, Zhejiang, 60 p.

$\underline{\text { Xu et al., } 2005}$ X.S. Xu, S.Y. O’Reilly, W.L. Griffin, P. Deng and N.J. Pearson, Relict Proterozoic basement in the Nanling mountains (SE China) and its tectonothermal overprinting, Tectonics 24 (2005), pp. 1-16. 
Xu et al., 2007 X.S. Xu, S.Y. O'Reilly, W.L. Griffin, X.L. Wang, N.J. Pearson and Z.Y. He, The crust of Cathaysia: age, assembly and reworking of two terranes, Precambrian Research 158 (1-2) (2007), pp. 51-78.

Yang et al., 2005 Q. Yang, Y.J. Wang, L.M. Yin, L.S. Shu, F.S. Lou and B. Wang, On the age of the ophiolitic complexes in northeastern Jiagxi: a micropaleontological analysis, Acta Geologica Sinica 79 (2005), pp. 801-805.

Ye et al., 2007 M. Ye, X.H. Li, W.X. Li, Y. Liu and Z.X. Li, SHRIMP zircon U-Pb geochronological and whole-rock geochemical evidence for an early Neoproterozoic Sibaoan magmatic arc along the southeastern margin of the Yangtze Block, Gondawana Research 12 (1-2) (2007), pp. 144-156.

Yu et al., 2006 J. Yu, Z. Wei, L. Wang, L.S. Shu and T. Sun, Cathaysia Block: a young continent composed of ancient materials, Geological Journal of China Universities 12 (2006), pp. $440-447$.

Yu et al., 2009 J.H. Yu, L.J. Wang, S.Y. O'Reilly, W.L. Griffin, M. Zhang, C.Z. Li and L.S. Shu, A Paleoproterozoic orogeny recorded in a long-lived cratonic remnant (Wuyishan terrane), eastern Cathaysia Block, China, Precambrian Research 174 (2009), pp. 347-363.

ZBGMR, 1989 ZBGMR (Zejiang Bureau of Geology and Mineral Resources), 1989. Regional Geology of Zhejiang Province. Geological Publishing House, Beijing, 688 p (in Chinese with English abstract).

Zeng et al., 2008 W. Zeng, L. Zhang, H.W. Zhou, Z.Q. Zhong, H. Xiang, R. Liu, S. Jin, X.Q. $\mathrm{Lu}$ and C.Z. Li, Caledonian reworking of Paleoproterozoic basement in the Cathaysia Block: constraints from zircon $\mathrm{U}-\mathrm{Pb}$ dating, $\mathrm{Hf}$ isotopes and trace elements, Chinese Science Bulletin 53 (6) (2008), pp. 895-904.

Zhang et al., 1984 Z.M. Zhang, J.G. Liou and R.C. Coleman, An outline of the plate tectonics of China, Geological Society of America Bulletin 95 (1984), pp. 295-312

Zhang et al., 1991 D.B. Zhang, J.T. Liang and Z.H. Buo, Study of the tectonic deformation and evolution in the northern segment of Wuyi-Yunkai tectonic zone. Bulletin of the Nanjing Institute of Geology and Mineral Resources, Chinese Academy of Geological Sciences 12 (3) (1991), pp. 37-48.

Zhang et al., 2005 Z.G. Zhang, J. Badal, Y.K. Li, Y. Chen, L.Q. Yang and J.W. Teng, Crustupper mantle seismic velocity structure across Southeastern China, Tectonophysics 395 (2005), pp. 137-157.

Zhang et al., 2008 S.H. Zhang, G.Q. Jiang, J. Dong, Y.G. Han and H.C. Wu, New SRIMP U$\mathrm{Pb}$ age from the Wuqiangxi Formation of Banxi Group: implications for rifting and stratigraphic erosion associated with the early Cryogenian (Sturtian) glaciation in South China, Science in China Series D - Earth Sciences 51 (11) (2008), pp. 1537-1544.

Zhao and Cawood, 1999 G. Zhao and P. Cawood, Tectonothermal evolution of the Mayuan assemblage in the Cathaysia Block: implications for neoproterozoic collision-related assembly of the South China Craton, American Journal of Science 299 (1999), pp. 309-339. 
Zhao et al., 1996 X. Zhao, M.B. Allen, A. Whitham and S. Price, Rift-related Devonian sedimentation and basin development in South China, Journal of Southeast Asian Earth Sciences 14 (1996), pp. 37-52.

Zheng et al., 2008 Y.F. Zheng, R.X. Wu, Y.B. Wu, S.B. Zhang, H. Yuan and F.Y. Wu, Rift melting of juvenile arc-derived crust: geochemical evidence from Neoproterozoic volcanic and granitic rocks in the Jiangnan Orogen, South China, Precambrian Research 163 (2008), pp. 351-383.

Zhou and Zhu, 1993 X.M. Zhou and Y.H. Zhu, Petrologic data from the Late Proterozoic collision-orogenic belt and suture zone in the southeast of China. In: J.L. Li, Editor, Crustal Structure and Geological Evolution of Southeast Continents, Publishing House of Metallurgy and Industry (1993), pp. 87-97.

\section{Figures and Tables}




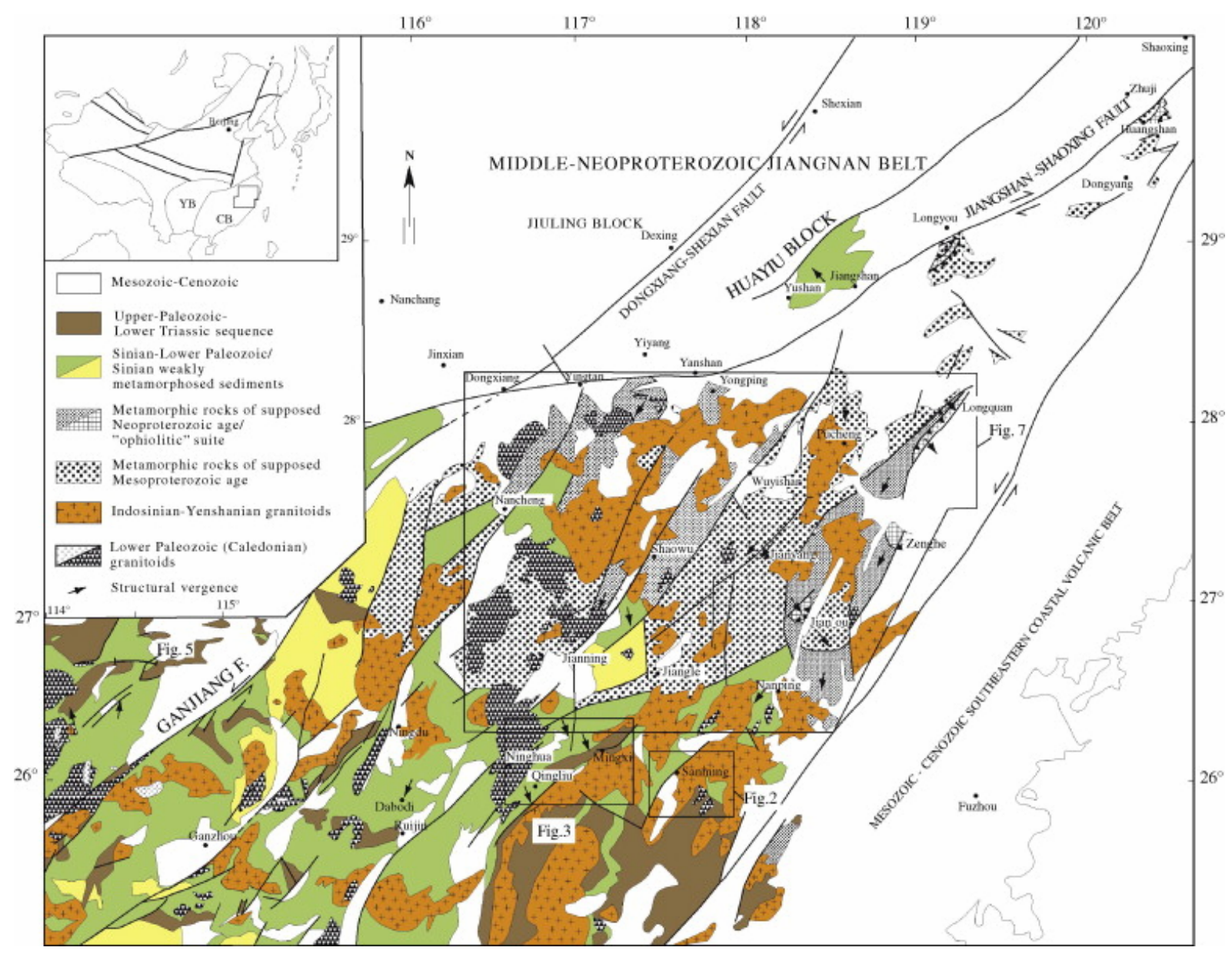

Fig. 1. Schematic geologic map of the studied area. The arrows indicate the average vergence of Early Paleozoic structures observed in the area, from macroscopic and microscopic criteria. The supposed ages of Proterozoic rocks are the ages of the protolith before the Early Paleozoic metamorphism. 


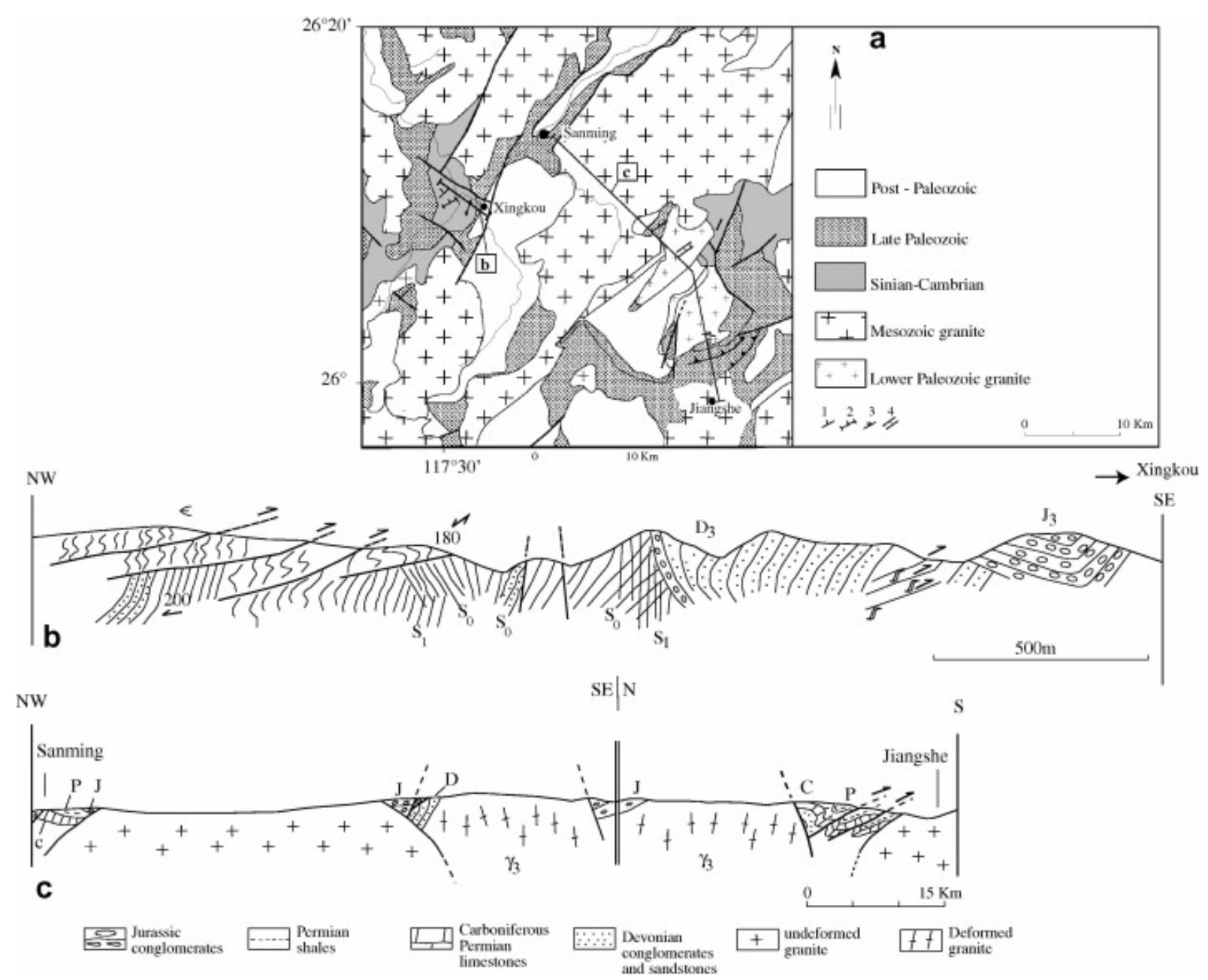

Fig. 2. Structures of the Sanming area. (a) Shematic geologic map, location on Fig. 1; 1: S1 dip; 2: S0 dip; 3: foliation in granite; 4: vertical foliation. (b) Xingkou cross-section. (c) Sanming-Jiangshe cross-section. 

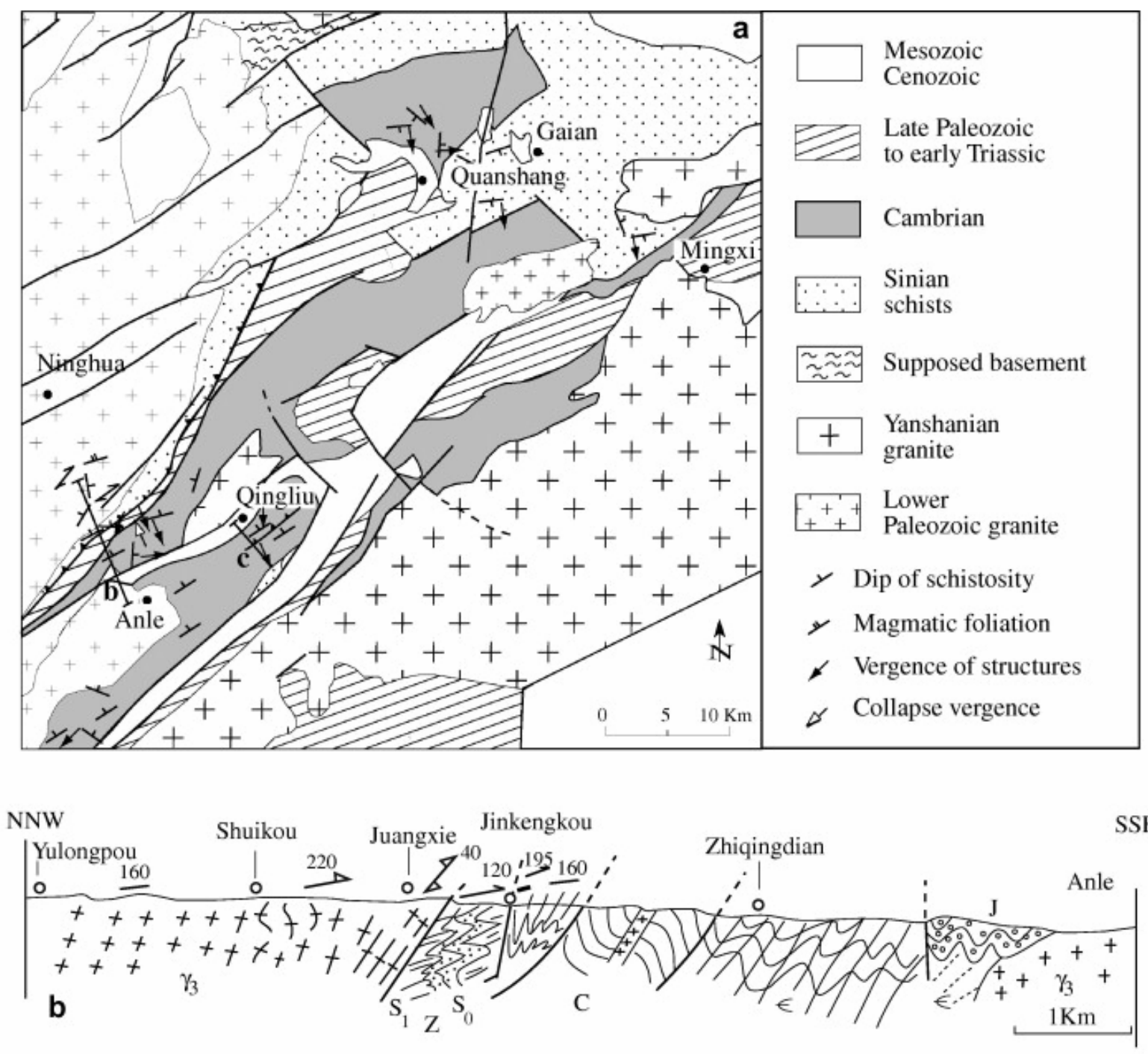

NW

SE

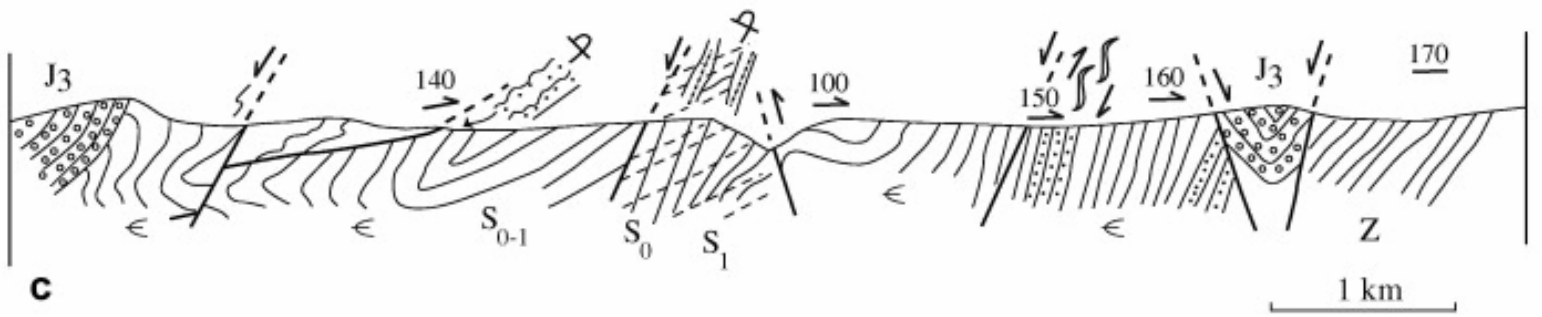

Fig. 3. Structures of the Qingliu area. (a) Schematic geologic map, location on Fig. 1. (b) Anle cross-section. (c) Qingliu cross-section. The trend of lineation is indicated either by a bar or an arrow when a sense of shear is determined; the arrow indicates the relative motion of the top. 

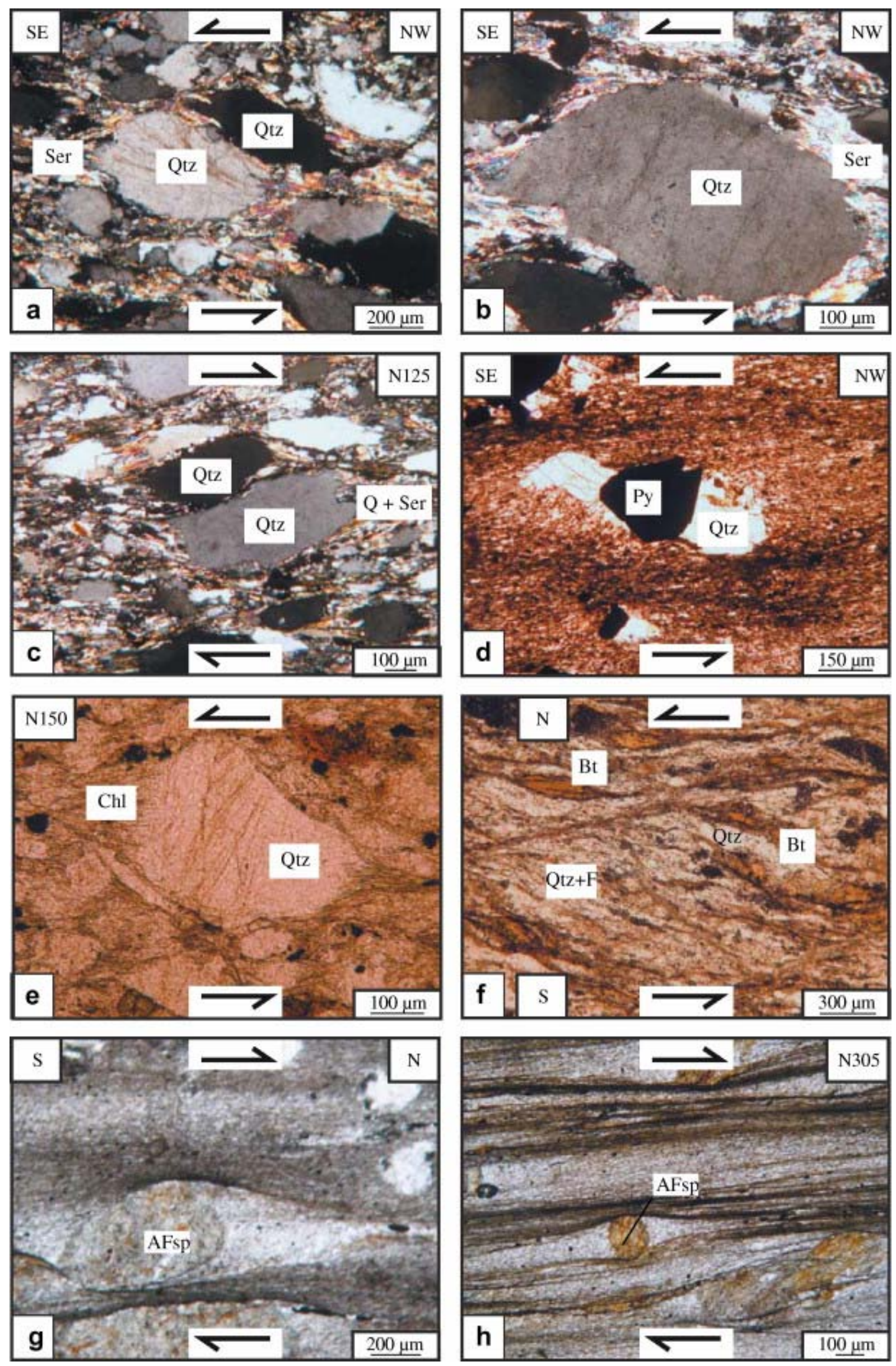
Fig. 4. Photomicrographs of kinematic criteria in Sinian-Ordovician schists of the sedimentary units. (a) WU-016, meta-sandstone, Ordovician, Huangxing (Quanshang), sericite asymmetric pressure shadows, top-to-the-SE shearing, CPL; (b) WU-016, metasandstone, Ordovician, Quanshang, asymmetric quartz-sericite pressure shadows, top-to-theSE shearing, CPL; (c) WU-018, meta-sandstone, Cambrian, Quanshang, quartz-sericite asymmetric pressure shadows, top-to-N125 shearing, CPL; (d) WU-017, metamicrosandstone, Cambrian, Quanshang, quartz fringes around pyrite, top-to-the- SE shearing, CPL; (e) WU-023, meta-sandstone, Sinian, Sachi River, Qingliu, chlorite asymmetric pressure shadows around quartz, top-to-N150 shearing, PPL; (f) WU-011, meta-graywacke, Quanshang, second phase shear bands on a steep foliation, northward sense of shear, PPL; $(\mathrm{g})$ WU-585, phyllite, Cambrian, Xiazhuang (S of Jinggangshan), sigmoidal quartz pressure shadows around clasts, top-to-the north shearing, PPL; (h) WU-586, phyllite, Cambrian, Xiazhuang, asymmetric pressure shadows around clasts, top-to-N305 sense of shear, PPL. AFsp; altered feldspar, transformed into aggregate of clay minerals; Bt: biotite; Chl: chlorite; Fsp: feldspar; Py: pyrite; Qtz: quartz; Ser: sericite.

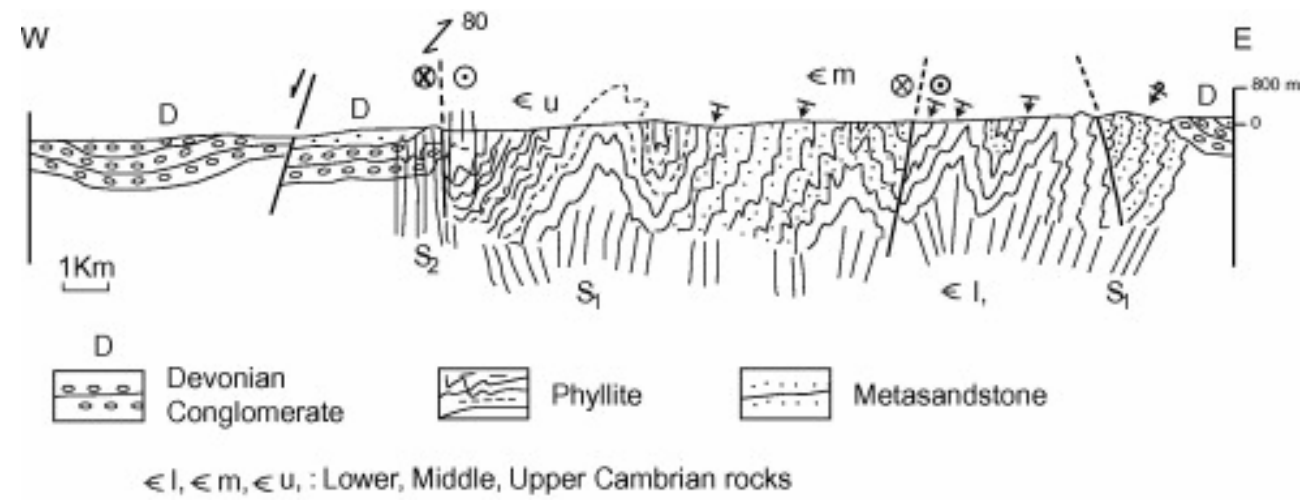

Fig. 5. Schematic cross-section of the Cambrian meta-sediments to the south of Jinggangshan, location on Fig. 1. 

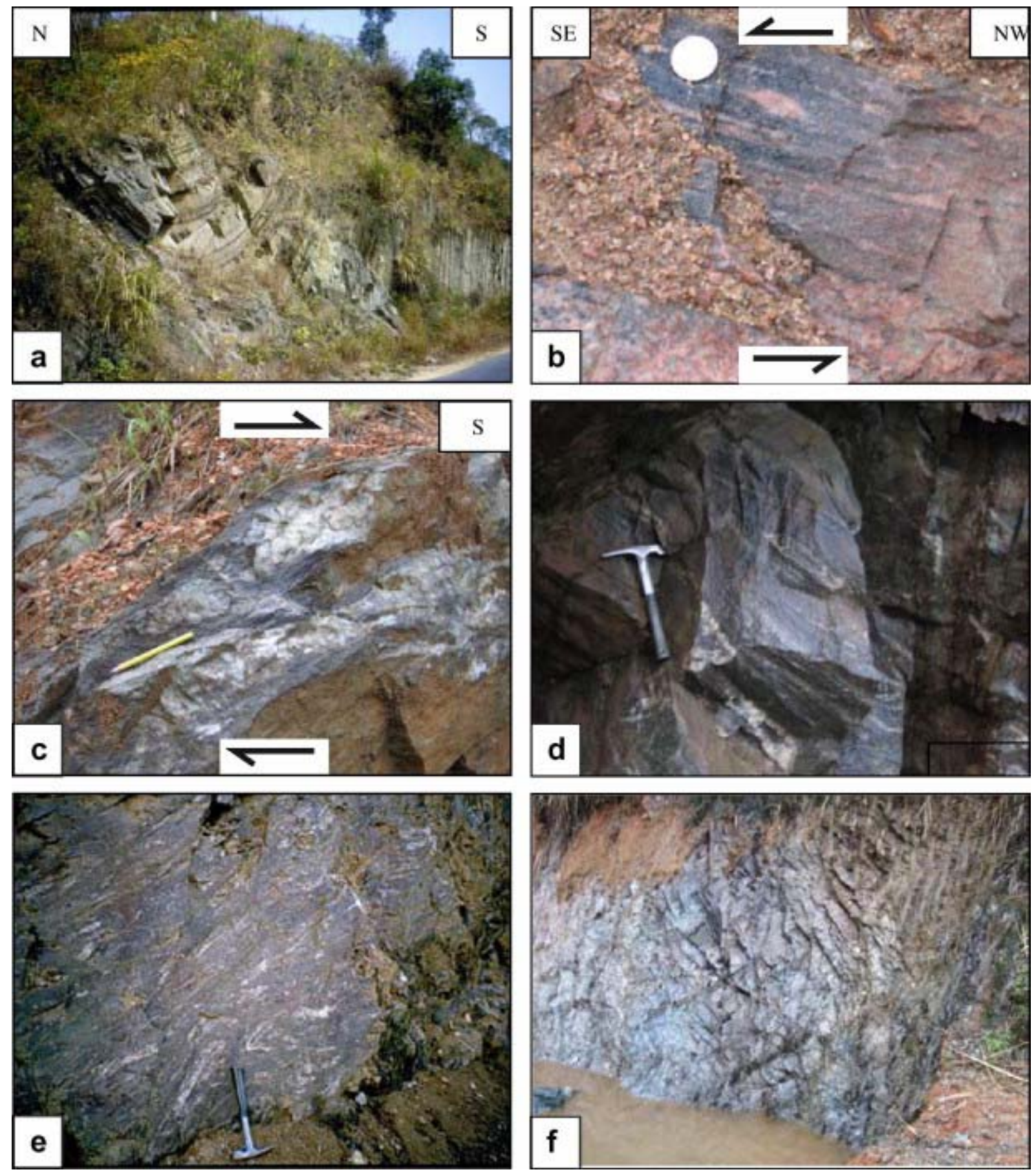

Fig. 6. Field outcrops. (a) Upper Cambrian strata, syncline slightly overturned toward the north, with incipient south-dipping fracture cleavage, Dasheng locality, Yushan area. (b) Sigmoidal leucosome part in migmatite, near Huangpu village (Jianning region), north of Ninghua granite, indicating a top-to-SE motion on a NW dipping foliation. (c) Quartz sigmoids in a garnet-biotite-bearing schist, near Lixin (Jianning region), top-to-S shearing. (d) Sheath-like folds of leucosome in a migmatic gneiss, near Luoyan (Jianning region). (e) Highly deformed quartz biotite schist, about $2 \mathrm{~km}$ NW of Jianyang, SE (left)-NW (right) exposure, near the basal contact of the upper unit in the cross-section of Fig. 8, the actual deformation is directed N230. (f) Chlorite schist, Xiayang unit of Fig. 16. 


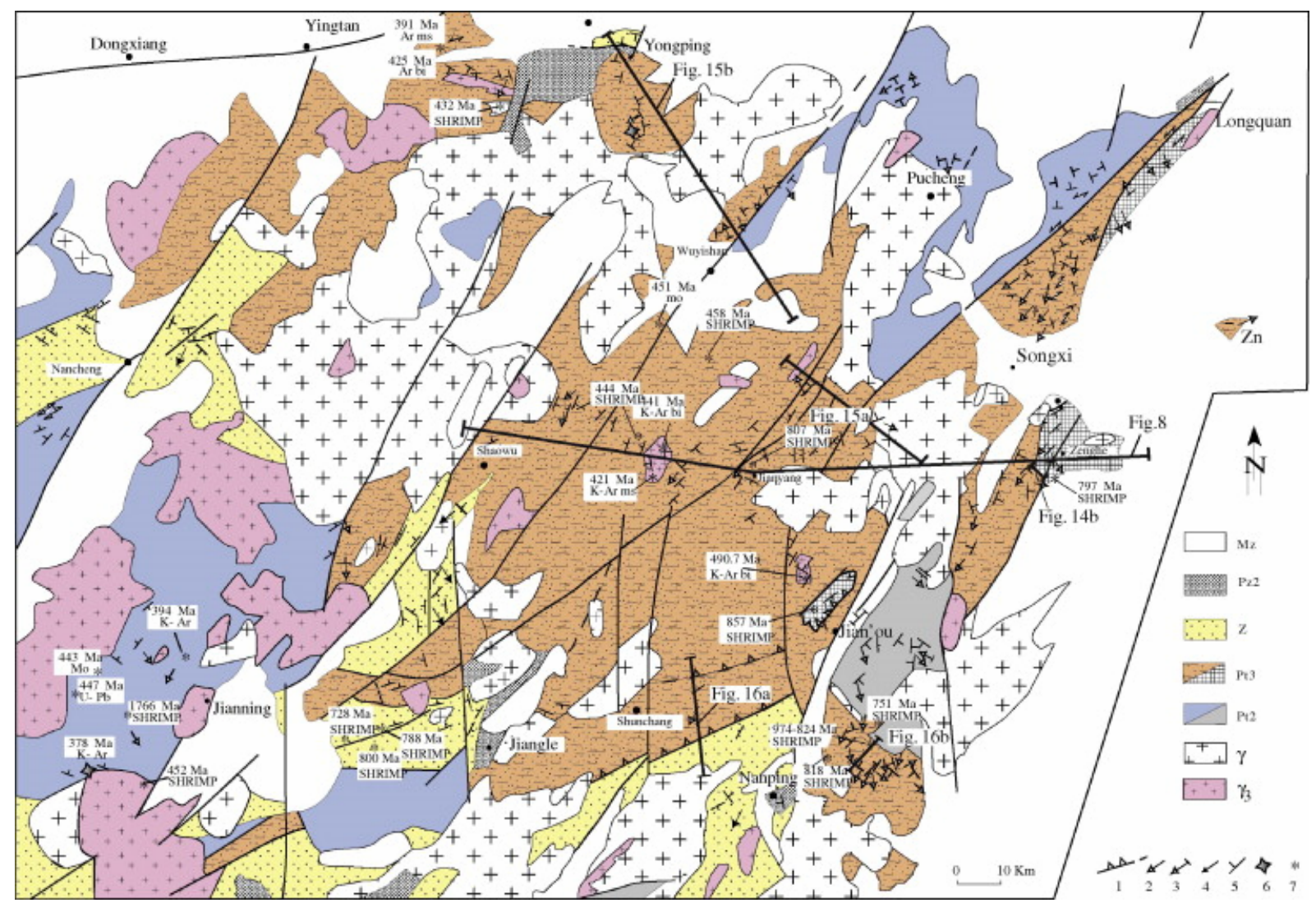

Fig. 7. Schematic geologic map of the studied Wuyishan metamorphic domain, location in Fig. 1. (1) thrust contact; (2) sense of shear in high grade rocks; (3) sense of shear assigned to an inherited structure or a late phase; (4) sense of shear in Sinian-Ordovician meta-sediments; (5) cleavage-foliation dip; (6) sample location for dating; (7) location of dating result from the literature (Ar: Ar-Ar method; K-Ar: K-Ar method; bi: biotite; ms: muscovite; mo: U-Th-Pb EPMA method on monazite). Data sources: (Li, 1997), (Li et al., 2005), (Li et al., 2009a), (Wan et al., 2007), (Chen et al., 2008) and (Zeng et al., 2008).

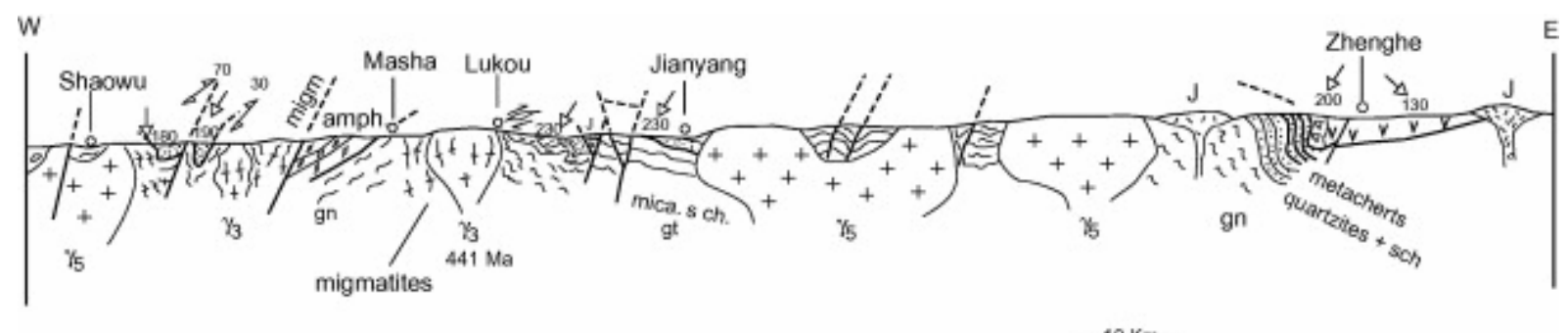

Fig. 8. Jianyang cross-section, location on Fig. 7. The arrows show the lineation direction and the determined sense of shear. 

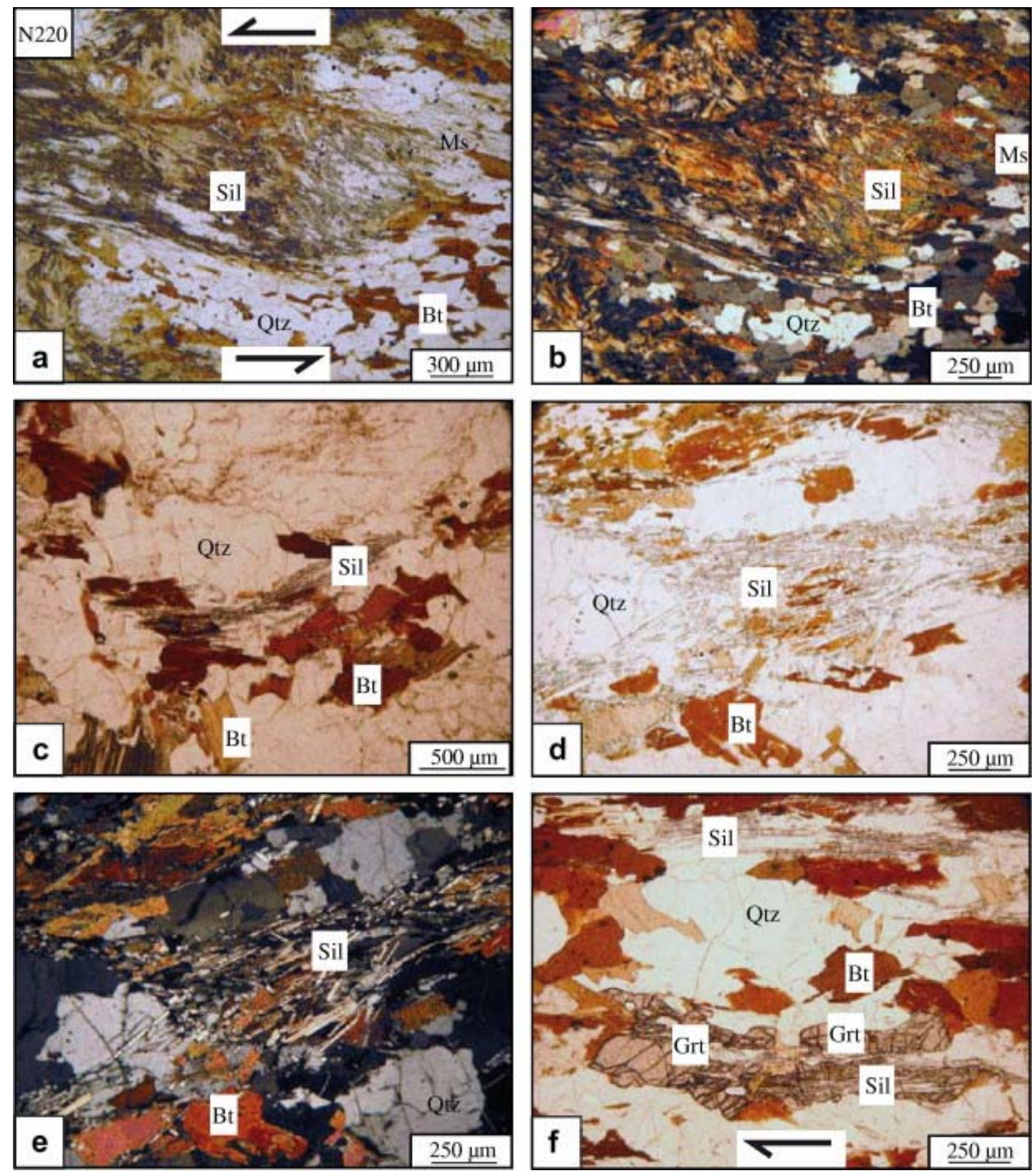

Fig. 9. Photomicrographs of metamorphic rocks with sillimanite paragenesis. (a) WU-094, Biotite muscovite sillimanite micaschist, Lukou, development of sillimanite prisms and fibrolites replacing garnet and respecting the general top-to-N220 kinematic, indicated by asymmetric biotite pressure shadows; some muscovite grains are also oblique on the foliation, PPL. (b) Idem, evidence of quartz static recrystallization, CPL. (c) WU-238, Zhuyang locality (N of Cizhu granite), biotite sillimanite gneiss, PPL. (d) WU-238, note some sillimanite prisms cross-cutting the foliation, PPL. (e) Idem, CPL. (f) WU-238B, note the sillimanite growing at the expense of garnet, PPL. Bt: biotite; Grt: garnet; Ms: muscovite; Qtz: quartz; Sil: sillimanite. 

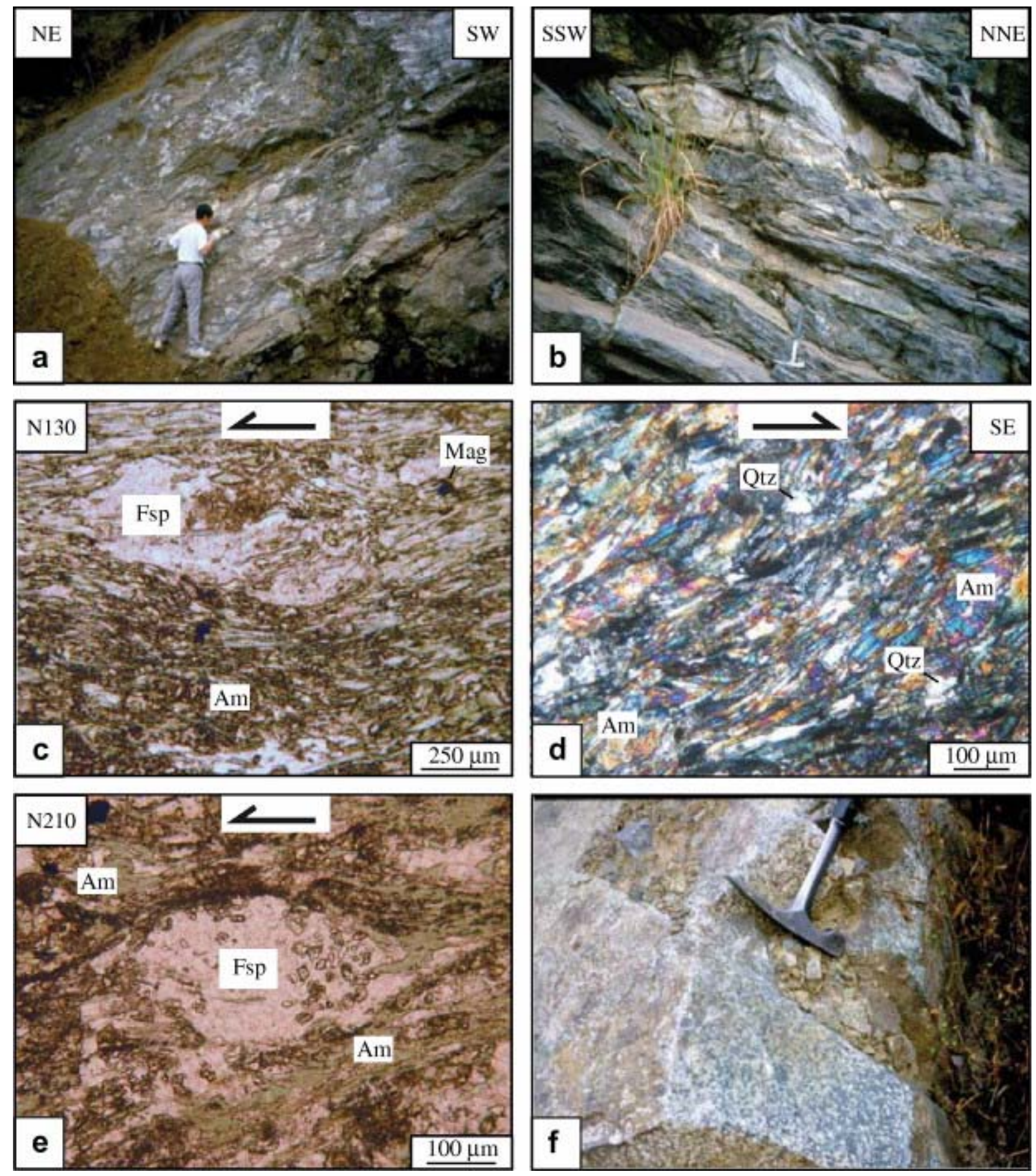

Fig. 10. Field outcrops and photomicrographs of basic-ultrabasic rocks. (a) Outcrop of basic greenschists and meta-pillow basalts, oriented NE-SW, Yuancheng Qiao (Jian'ou); note some sigmoids indicating a southward shearing. (b) Same locality, closer view of another outcrop oriented SSW-NNE; note the meta-pillow (upper left corner) and some sigmoids (picture centre above the hammer) indicating a southward shearing. (c) WU-072, photomicrograph of the Jian'ou amphibole schist, asymmetric amphiboles around feldspar porphyroclast, top-toN130 sense of shear, PPL. (d) WU-473, amphibole schist, Jian'ou, shear bands and sigmoids indicating a top-to-SE sense of shear, CPL. (e) WU-061, Fuyan, SSW of Zhenghe, amphibole meta-basic greenschist, asymmetric feldspar porphyroclast indicating a top-to-N210 sense of shear, PPL. (f) Outcrop view of the Huaquan gabbro. Am: amphibole; Fsp: feldspar; Mag: magnetite; Qtz: quartz. 

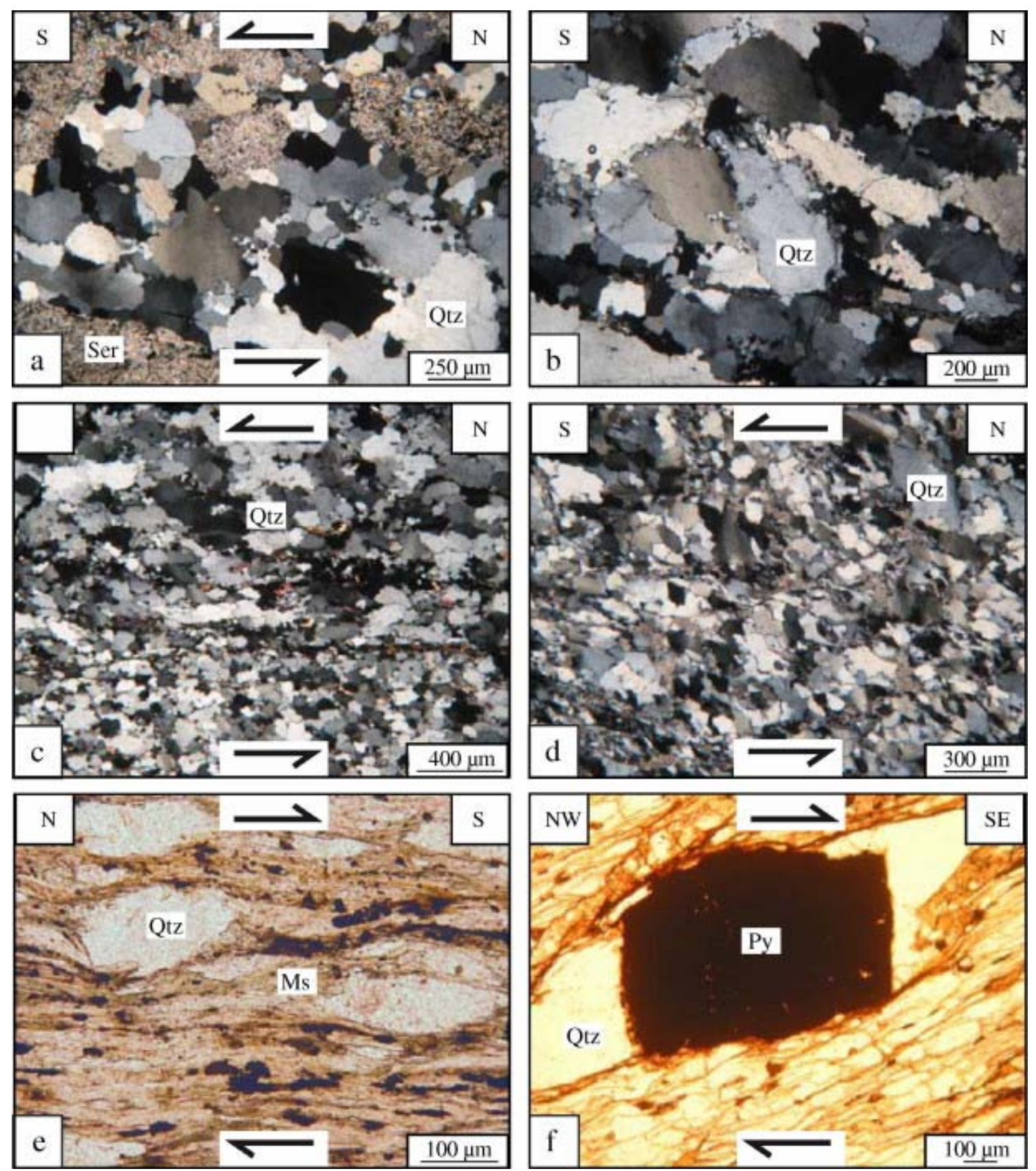

Fig. 11. Photomicrographs of meta-siliceous rocks. (a) WU-099, Qitou (Lukou area), sericite quartzite, incipient dynamic quartz recrystallization by bulging (BLG), shearing toward N190, CPL. (b) WU-100, between Qitou and Shaowu, quartz schist mylonite, note the sub-grains and the birth of small quartz crystals by bulging, fabric toward the south, CPL. (c) WU-067, S of Zhenghe, bedded quartzite (metachert), strong dynamic quartz recrystallization by bulging, the fabric indicates a top-to-N200 (left) sense of shear, CPL. (d) WU-046, Yekeng bridge (Longbeixi area), muscovite quartzite, dynamic recrystallization by sub-grain rotation, shearing toward N190 (left), CPL. (e) WU-041, Longbeixi, siliceous marble, quartz recrystallization by SGR and BLG, fabric toward the south, CPL. (f) WU-049, near Xiazhuang (Longbeixi area), quartzite mylonite, dynamic quartz recrystallization by SGR, fabric toward the south, CPL. (g) WU-042, Longbeixi, quartz muscovite schist, asymmetric muscovite pressure shadows around quartz porphyroclasts, top-to-N160 sense of shear. PPL. (h) WU-065, S outskirts of Zhenghe, metachert, quartz fringes around pyrite, top-to-N130 sense of shear, PPL. Ms: muscovite; Py: pyrite; Qtz: quartz; Ser: sericite. 

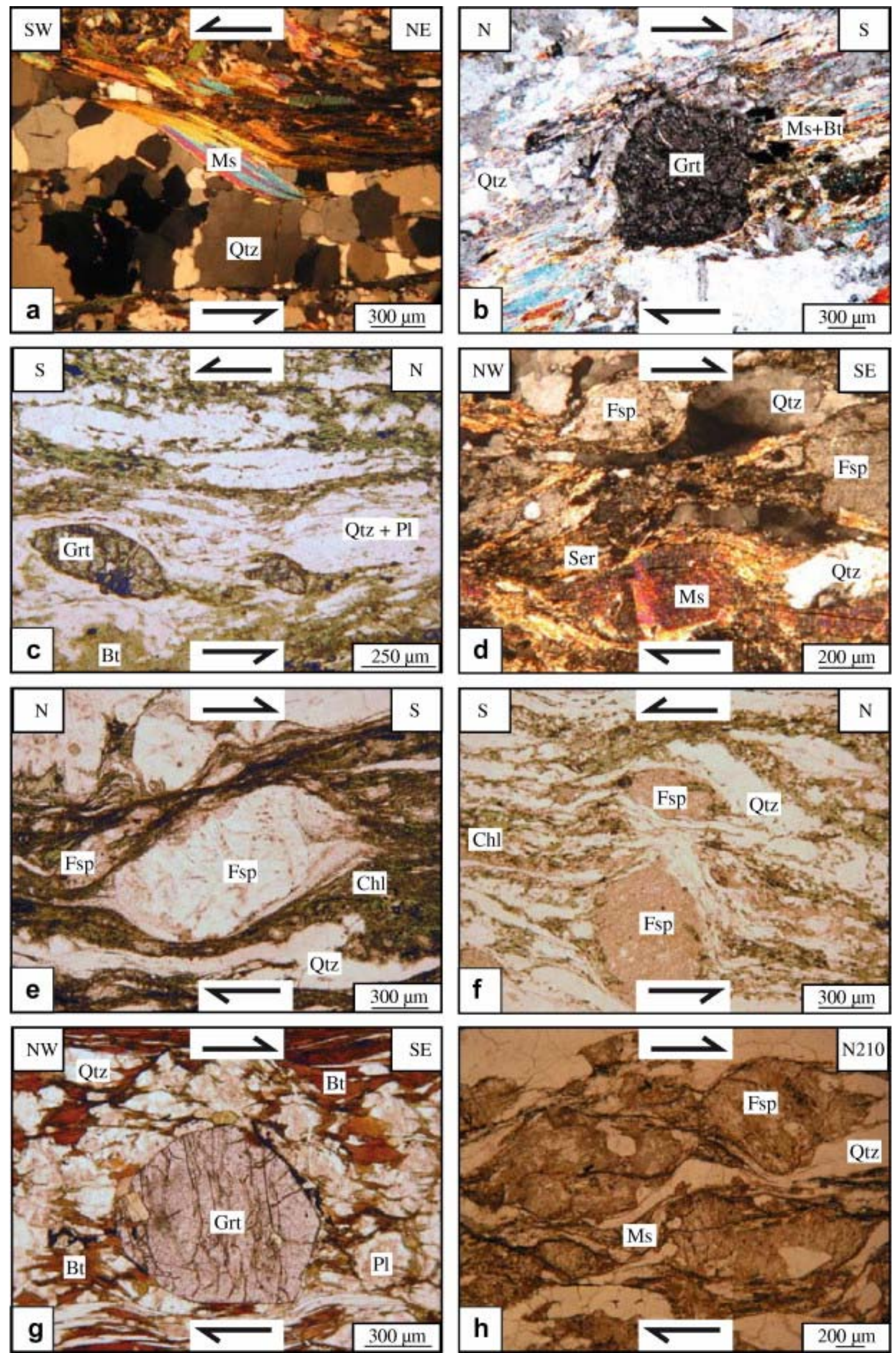
Fig. 12. Photomicrographs of kinematic criteria in meta-pelitic rocks, othogneisses, migmatites. (a) WU-088, garnet micaschist, $2 \mathrm{~km} \mathrm{NW}$ of Jianyang, muscovite fish indicating a top-to-N220 sense of shear, exsudation quartz vein, CPL. (b) WU-768, garnet micaschist, Xiayang, top-to-S sense of shear, CPL. (c) WU-173, garnet micaschist, Chenbien (SE of Longquan), sigmoidal garnets, top-to-N200 sense of shear, PPL. (d) WU-035, muscovite rich gneiss, Xiaoqiao (E of Jian'ou), shear bands, mica fish, quartz tails and cataclastic deformation, top-to-N150 sense of shear, CPL. (e) WU-216A, Dongting (Pucheng area), mylonitic gneiss, asymmetric pressure shadows around sigmoidal feldspar porphyroclats, topto-N200 sense of shear, PPL. (f) WU-171, Jixia (S of Longquan), mylonitic gneiss, asymmetric pressure shadows around feldspar porphyroclasts, top-to-N210 sense of shear, PPL. (g) WU-222, near Xikeng (Pucheng area), garnet biotite schist, asymmetric pressure shadows around garnet and shear bands, top-to-SE sense of shear, PPL. (h) WU-215, Weitian (Pucheng area), gneiss mylonite, deformed feldspar porphyroclasts, muscovite-quartz pressure shadows, top-to-N210 sense of shear. Bt: biotite; Chl: chlorite; Fsp: feldspar; Grt: garnet; Ms: muscovite; PL: plagioclase; Qtz: quartz; Ser: sericite. 

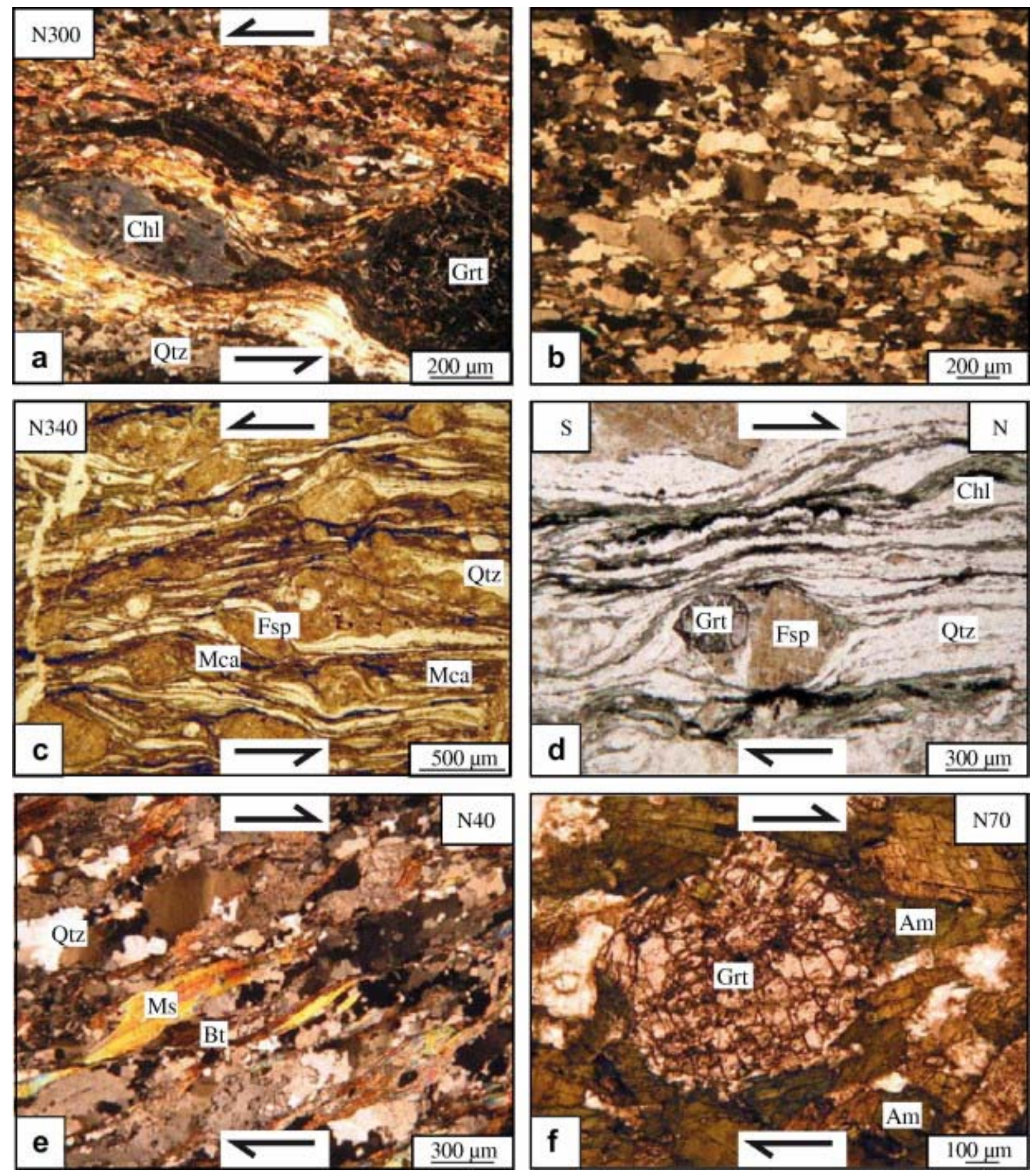

Fig. 13. Photomicrographs showing north-verging deformation in the high grade metamorphic units, Longquan-Qingyuan area. (a) WU-124, late retrograde stage shear bands, with sigmoidal chlorite replacing biotite and destabilized garnet, in a garnet-bearing quartz-mica schist. Anji, Longquan area. Top-to-N sense of shear, last phase of collapse, CPL. (b) WU124, garnet micaschist, Anji, dynamically recrystallized quartz, BLG, CPL. (c) WU-129A, mylonite in orthogneiss, Xikou (S Longquan), asymmetric tails around KF, top-to-N340 main sense of shearing, PPL. (d) WU-131, mylonite with asymmetric pressure shadows around KF showing a top-to-N350 sense of shear, superimposed by static garnet growing on previous minerals (feldspar, quartz), Xikou, Longquan area, PPL. (e) WU-137, biotite and garnetbearing quartz-mica schist, Shatian (S Longquan), muscovite fish indicating a top-to-N40 sense of shear, CPL. (f) WU-178, garnet amphibolite, Zhangcun (Qinyuan area), top-to-N70 
sense of shear, PPL. Am: amphibole; Bt: biotite; Chl: chlorite; Fsp: feldspar; Grt: garnet; Mca: mica; Ms: muscovite; Qtz: quartz.
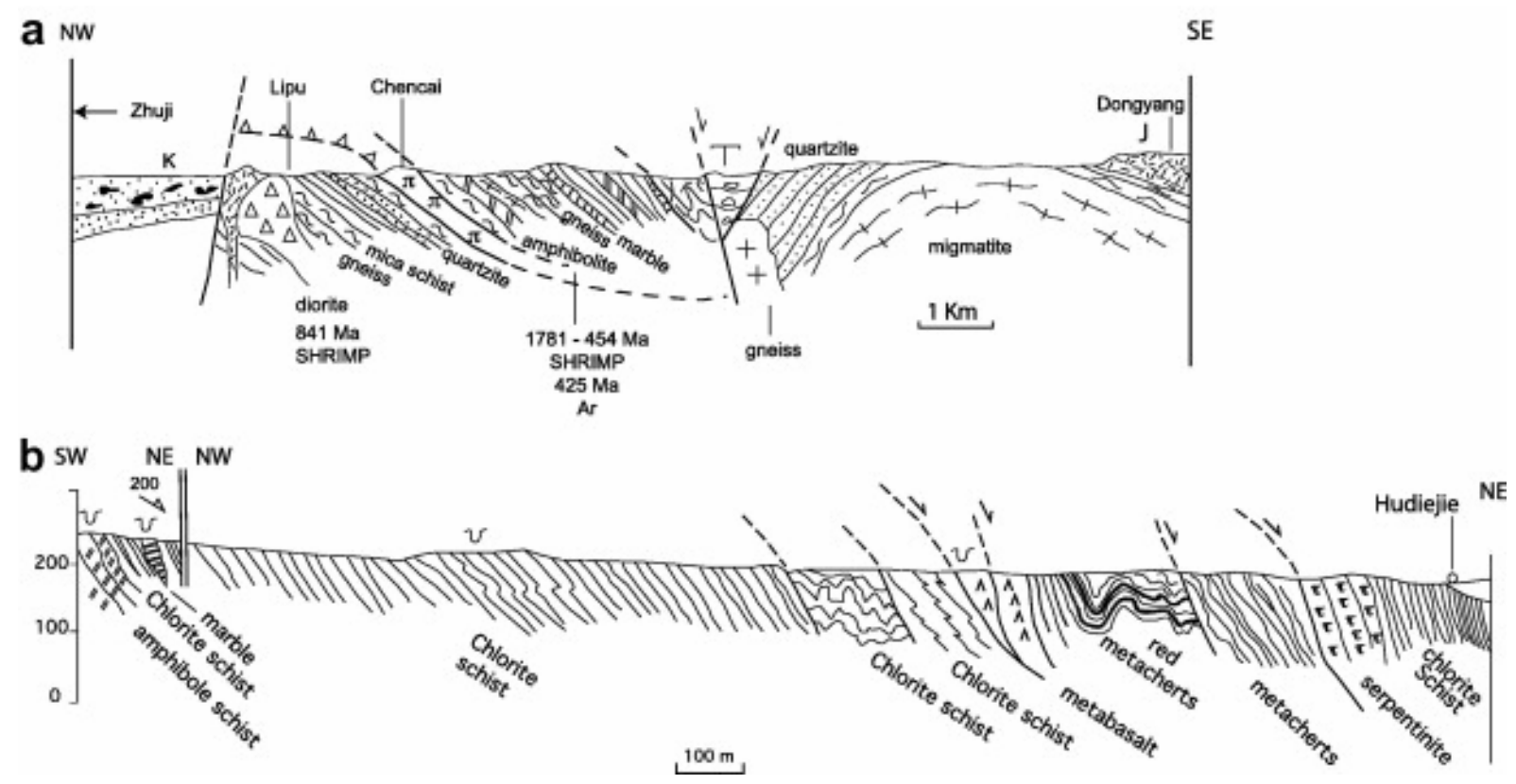

Fig. 14. Cross-sections of mafic-ultramafic rocks-bearing thrust sheets, location on [Fig. 1] and [Fig. 7]. (a) Chencai cross-section, modified after Charvet et al. (1999) and Shui et al. (1988)and (b) Hudiejie cross-section. Radiometric ages after Li et al. (2009b).

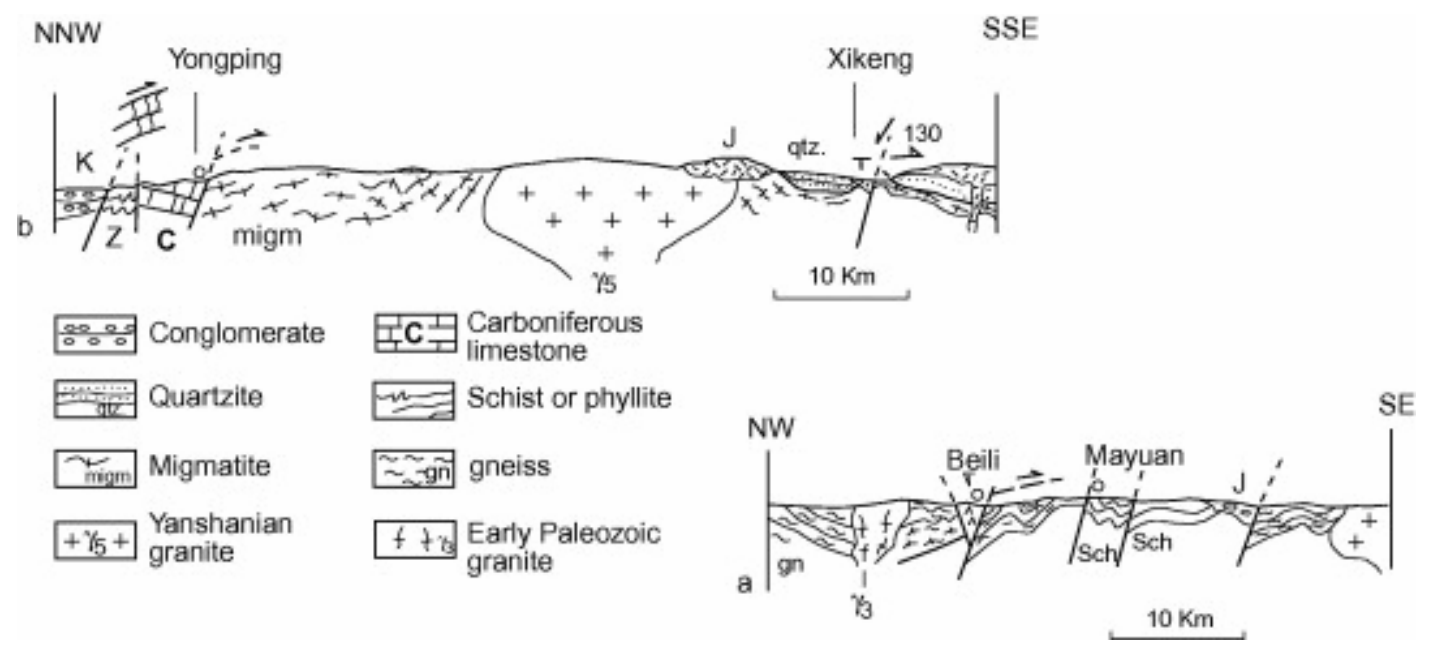

Fig. 15. Yongping and Beili cross-sections, location on Fig. 7. (a) Beili section and (b) Yongping section. 
a $\mathrm{N}$

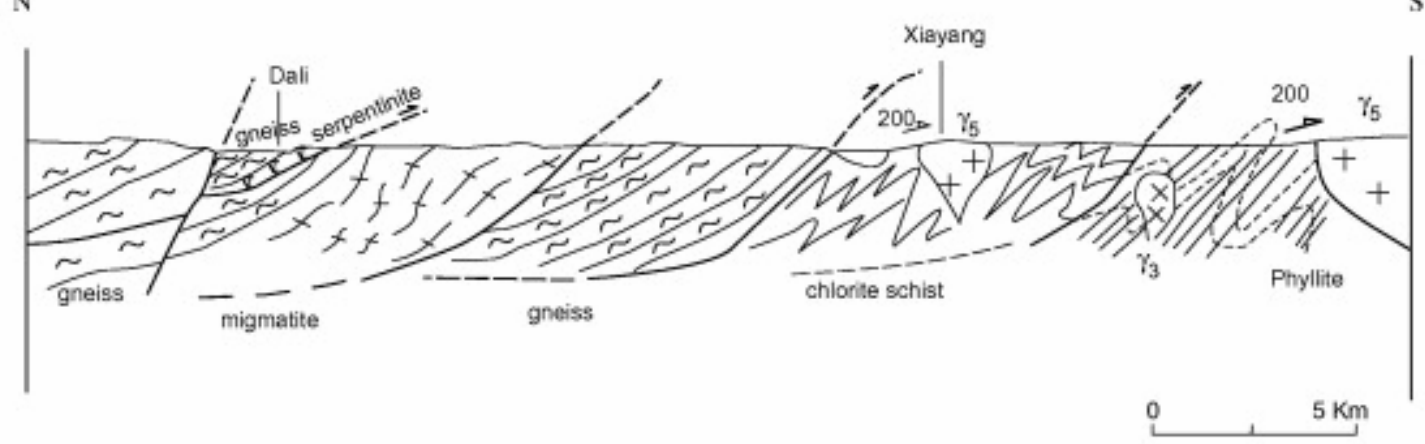

b SW

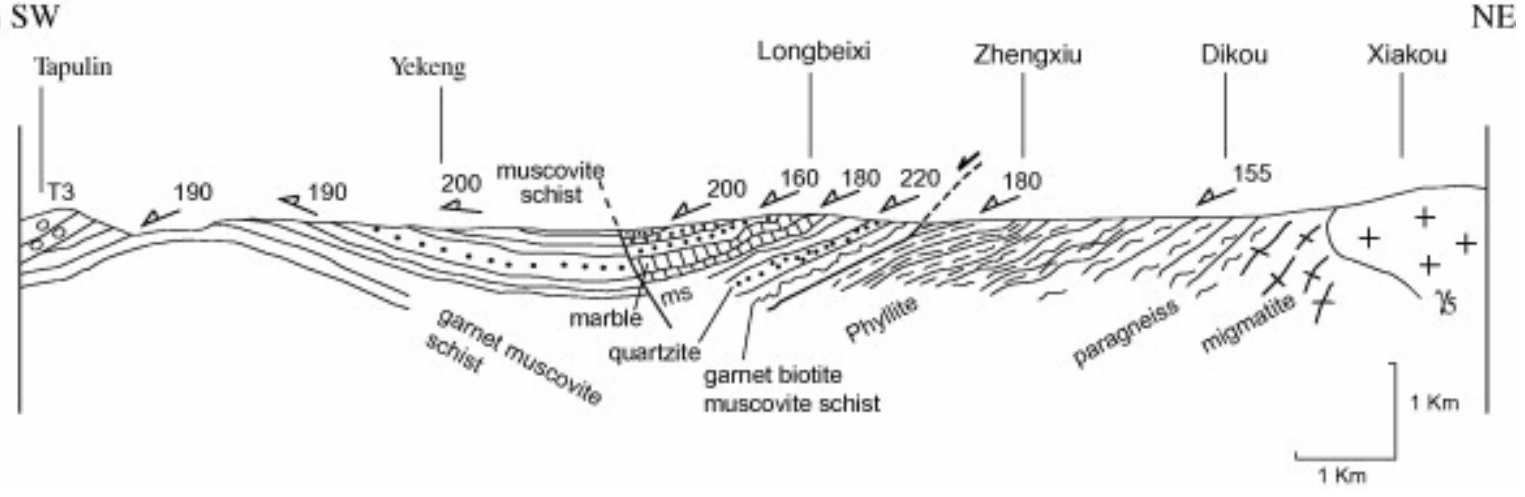

Fig. 16. Dikou-Longbeixi cross-section, location on Fig. 7.
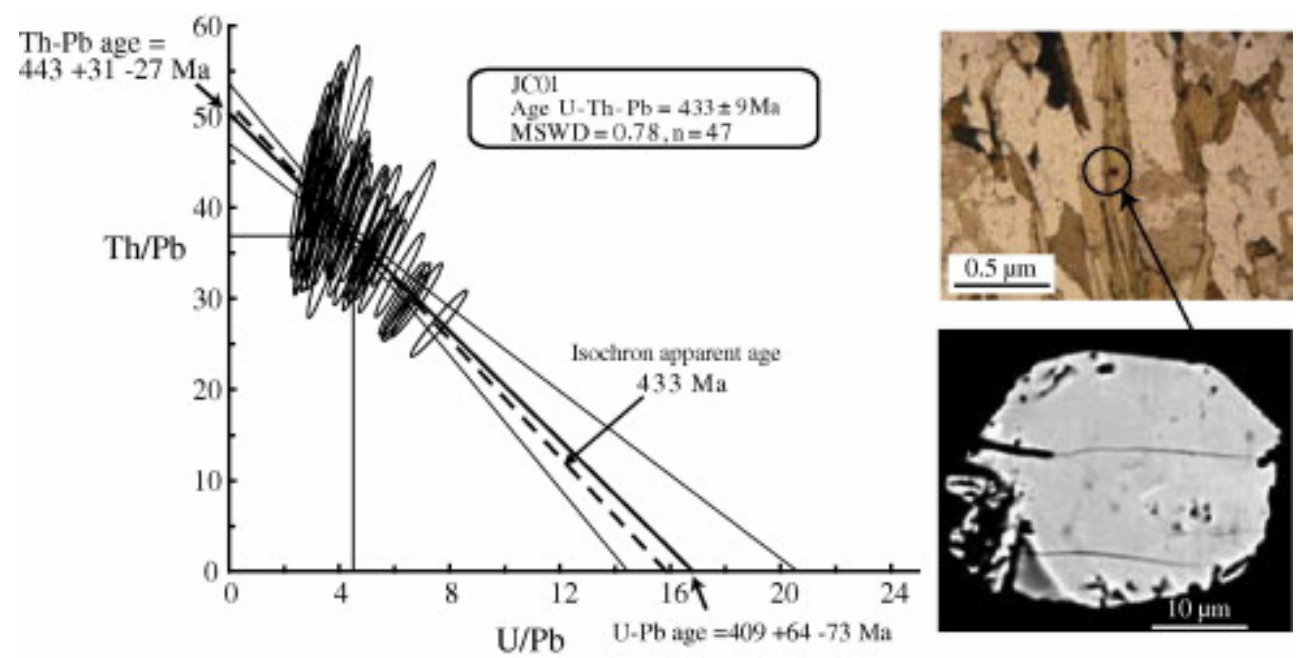

Fig. 17. Geochronological data. Results of sample WU-227-JC01. Photomicrographs, BSE images and $\mathrm{Th} / \mathrm{Pb}$ vs. $\mathrm{U} / \mathrm{Pb}$ diagram. 

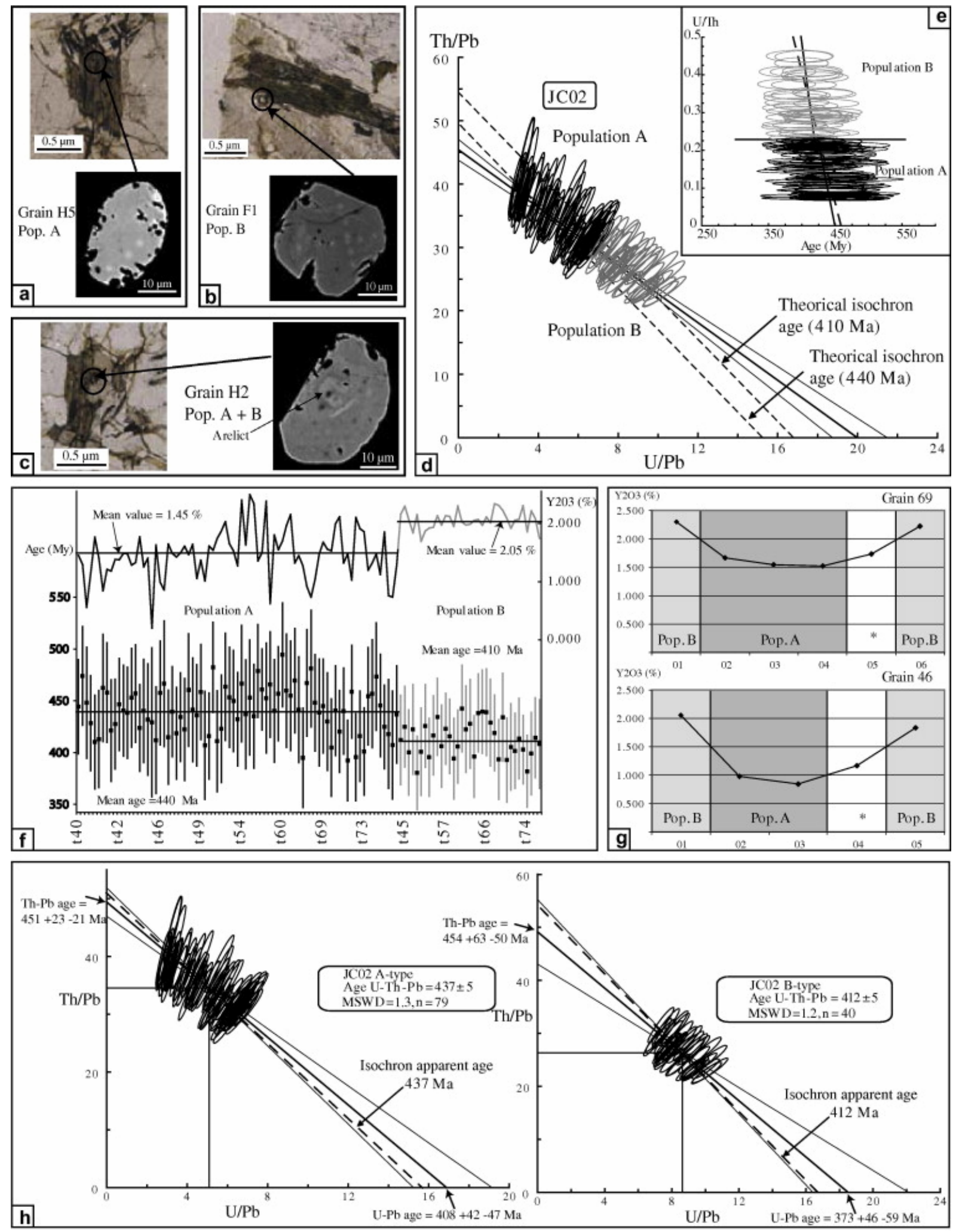

Fig. 18. Geochronological data. Results of sample WU-816-JC02; (a-c) Th/Pb vs. U/Pb diagram Photomicrographs and BSE images for A, B and hybrid population; (d) Th/Pb vs. $\mathrm{U} / \mathrm{Pb}$ diagram for all results; (e) U/Th vs. age diagram for all results; (f) comparison of $\mathrm{Y}_{2} \mathrm{O}_{3}$ content and age of both populations; $(\mathrm{g})$ variations of $\mathrm{Y}_{2} \mathrm{O}_{3}$ content in grain 46 and 69; (h) $\mathrm{Th} / \mathrm{Pb}$ vs. $\mathrm{U} / \mathrm{Pb}$ diagrams for $\mathrm{A}$ and $\mathrm{B}$ population respectively. 

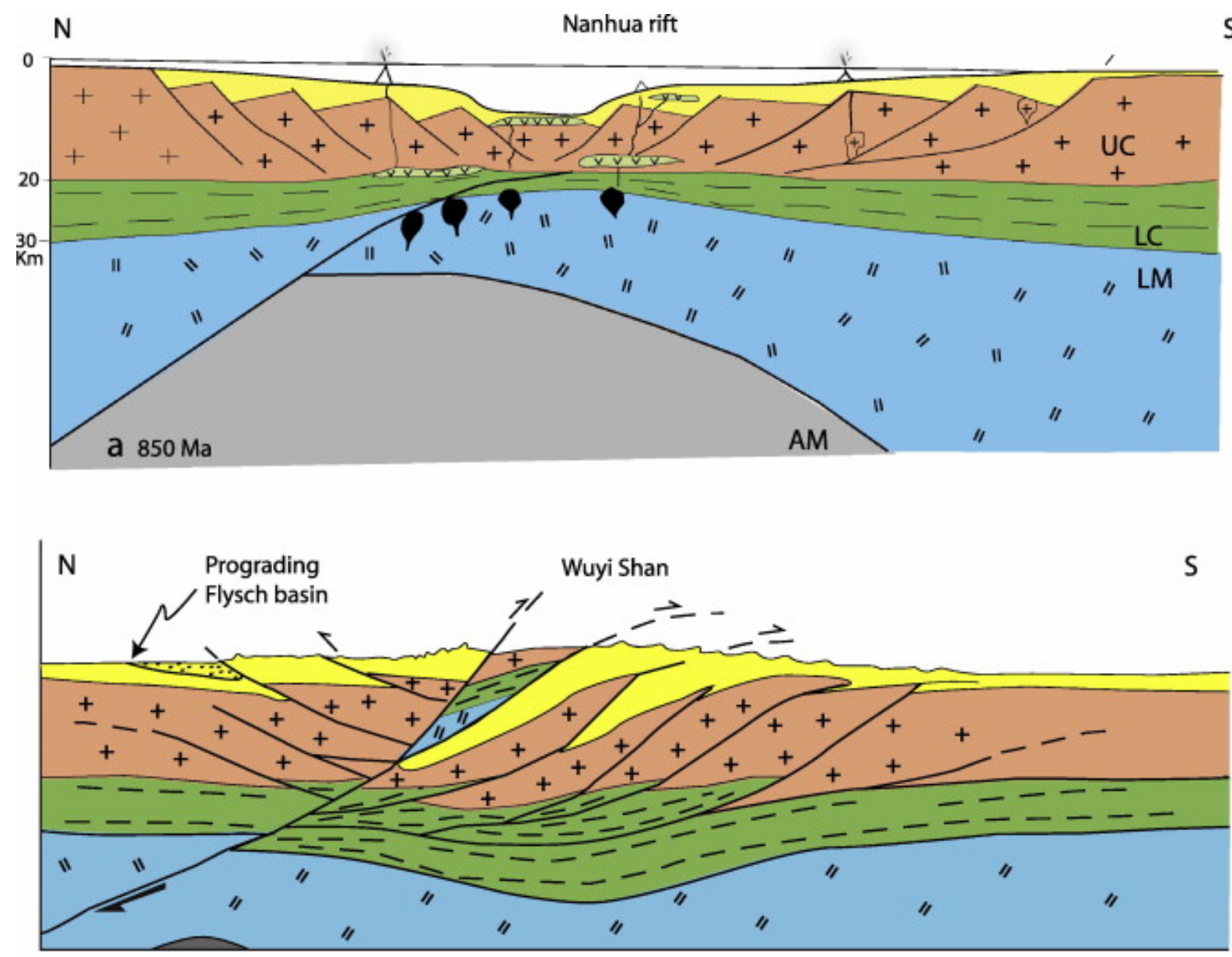

b $460 \mathrm{Ma}$

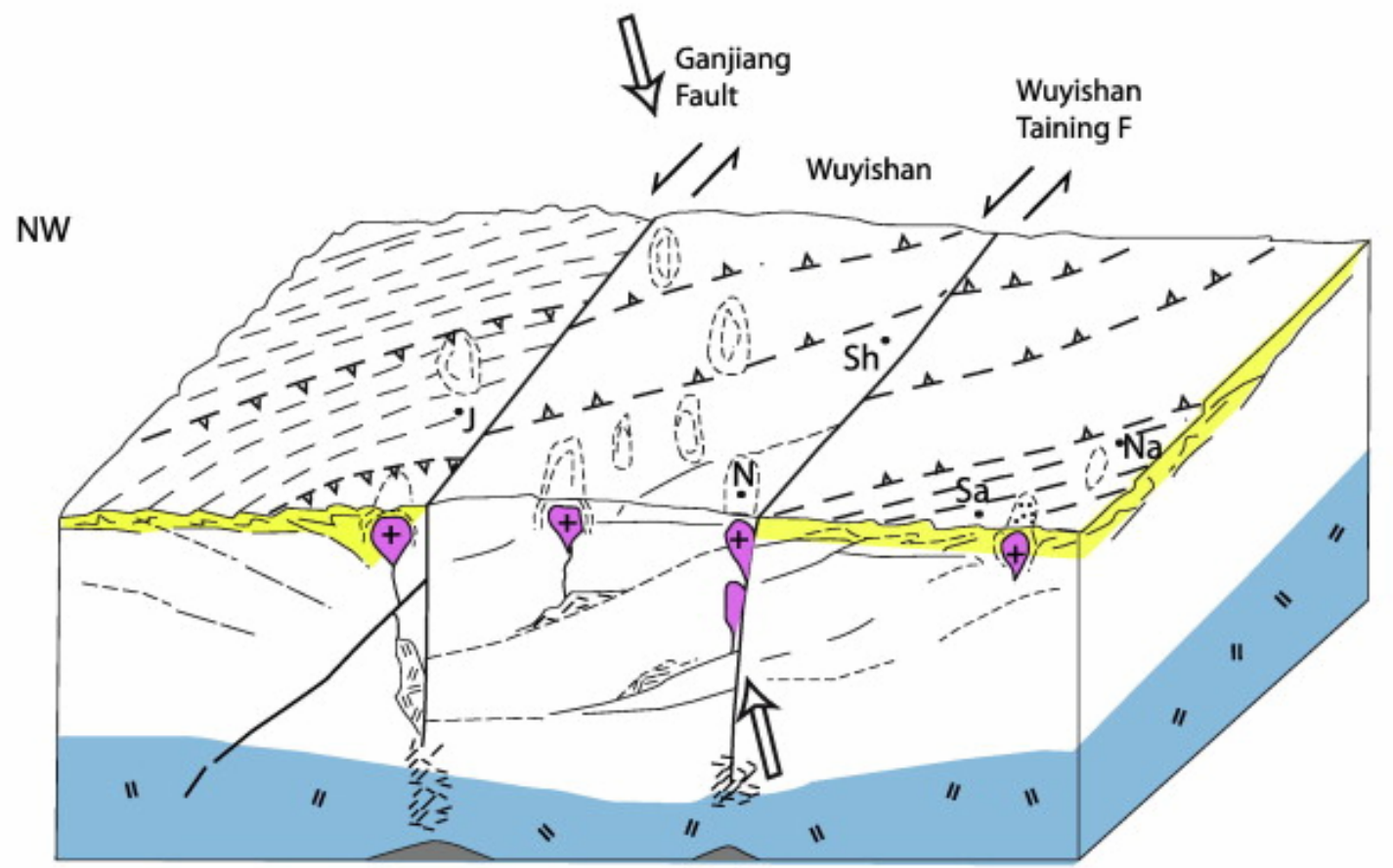

\section{C $440 \mathrm{Ma}$}


Fig. 19. Geodynamic evolutionary model. (a) around $850 \mathrm{Ma}$, rifting stage; (b) around $460 \mathrm{Ma}$, compressional stage, piling of nappes and prograde metamorphism; (c) around 440$430 \mathrm{Ma}$, anatexis, emplacement of granitoids, maybe accompanied by a sinistral transpression. AM: asthenospheric mantle; LM: lithospheric mantle; LC: lower crust; UC: upper crust. J: Jinggangshan; N: Ninghua; Na: Nanping; Sa: Sanming; Sh: Shaowu. 